\title{
Shark fossil diversity (Squalomorphii, Squatinomorphii, and Galeomorphii) from the Langhian of Brielas (Lower Tagus Basin, Portugal)
}

\author{
Pedro R. Fialho, ${ }^{1,2}$ | Ausenda C. Balbino, ${ }^{1,2,3}$ | Paulo Legoinha ${ }^{2}$ | Miguel T. Antunes,
}

${ }^{1}$ Departamento de Geociências, Escola de Ciências e Tecnologia, Universidade de Évora, Évora, Portugal

${ }^{2}$ GeoBioTec, Faculdade de Ciências e Tecnologia, Universidade Nova de Lisboa, Caparica, Portugal

${ }^{3}$ Academia das Ciências de Lisboa, Lisbon, Portugal

\section{Correspondence}

Pedro R. Fialho; Departamento de

Geociências, Escola de Ciências e Tecnologia, Universidade de Évora, Rua Romão Ramalho, 59, 7000-671 Évora, Portugal.

Email: prfialho181@gmail.com

Handling Editor: I. Somerville
The fossiliferous marine Miocene sediments of the Lower Tagus Basin (Portugal) present a great diversity of Chondrichthyes forms. The current study focuses on the fossil sharks from the Langhian Vc unit of the Brielas section, located in the Setúbal Peninsula. A total of 384 isolated fossil teeth were analysed and ascribed to 17 species from the Orders Hexanchiformes, Squaliformes, Squatiniformes, Lamniformes, and Carcharhiniformes. Centrophorus granulosus and lago angustidens are described for the first time in Portuguese sediments, whereas Pachyscyllium dachiardii and Rhizoprionodon ficheuri represent only their second reported occurrence. Galeorhinus goncalvesi was already known from the Portuguese uppermost Miocene (Alvalade Basin), but it is now recognized in older sediments. Furthermore, the new material seems to include the first reported occurrence of Hexanchus cf. agassizi in Miocene sediments. As a whole, these new findings support the previous palaeoenvironment characterization of a warm infralittoral setting gradually deepening to a circalittoral one, where seasonal upwelling phenomena could have occurred.

\section{KEYWORDS}

Chondrichthyes, fossil sharks, Lower Tagus Basin, Miocene, Portugal, teeth

\section{1 | INTRODUCTION}

For almost 50 years, since the earlier work by Antunes and Jonet (1970) on Lisbon's Serravallian-Tortonian fossil sharks, the Brielas outcrop has been known for its fossil-rich sedimentary beds. This site is located in one of the six main Portuguese Cenozoic basins (Pais et al., 2012), the Lower Tagus Basin, in the Setúbal Peninsula (West Portugal), adjacent to the Costa de Caparica highway, as depicted in Figure 1. Due to the abundance of fossil teeth, high taxonomic diversity, adequate taphonomic preservation, good available reference collections, and high-resolution biostratigraphy, we may consider Brielas as an important fossil site for the knowledge of the Iberian Peninsula (mid to late) Miocene fossil sharks.

Foraminifera from the Brielas outcrop were studied by Legoinha (2001). The correlation of the Lower Tagus Basin lithostratigraphic units with the standard calcareous nannoplankton biozones was attempted by Legoinha and Flores (2014). Later on, the authors studied the fossil batoid fauna, with 12 identified species (Fialho et al., 2019). The current work aims to complement the last study, with detailed systematic analysis of the shark assemblage of this site.

\section{2 | GEOLOGICAL SETTING}

In the Cenozoic Lower Tagus Basin, the Miocene succession presents a well-known and rather complete marine record, from the Aquitanian to the Early Tortonian. Ten depositional sequences were recognized (Antunes, Legoinha, Proença Cunha, \& Pais, 2000; Legoinha, 2001; Pais et al., 2012), each one initiated by a transgressive surface with shallow marine deposits changing upwards to more distal marls (transgressive system tract), and overlaid by highstand progradational deposits related to hinterland fluvial systems and siliciclastic sedimentation. Vertebrate fossils, namely small mammals known from fluvial deposits interbedded in the marine succession with planktic and 


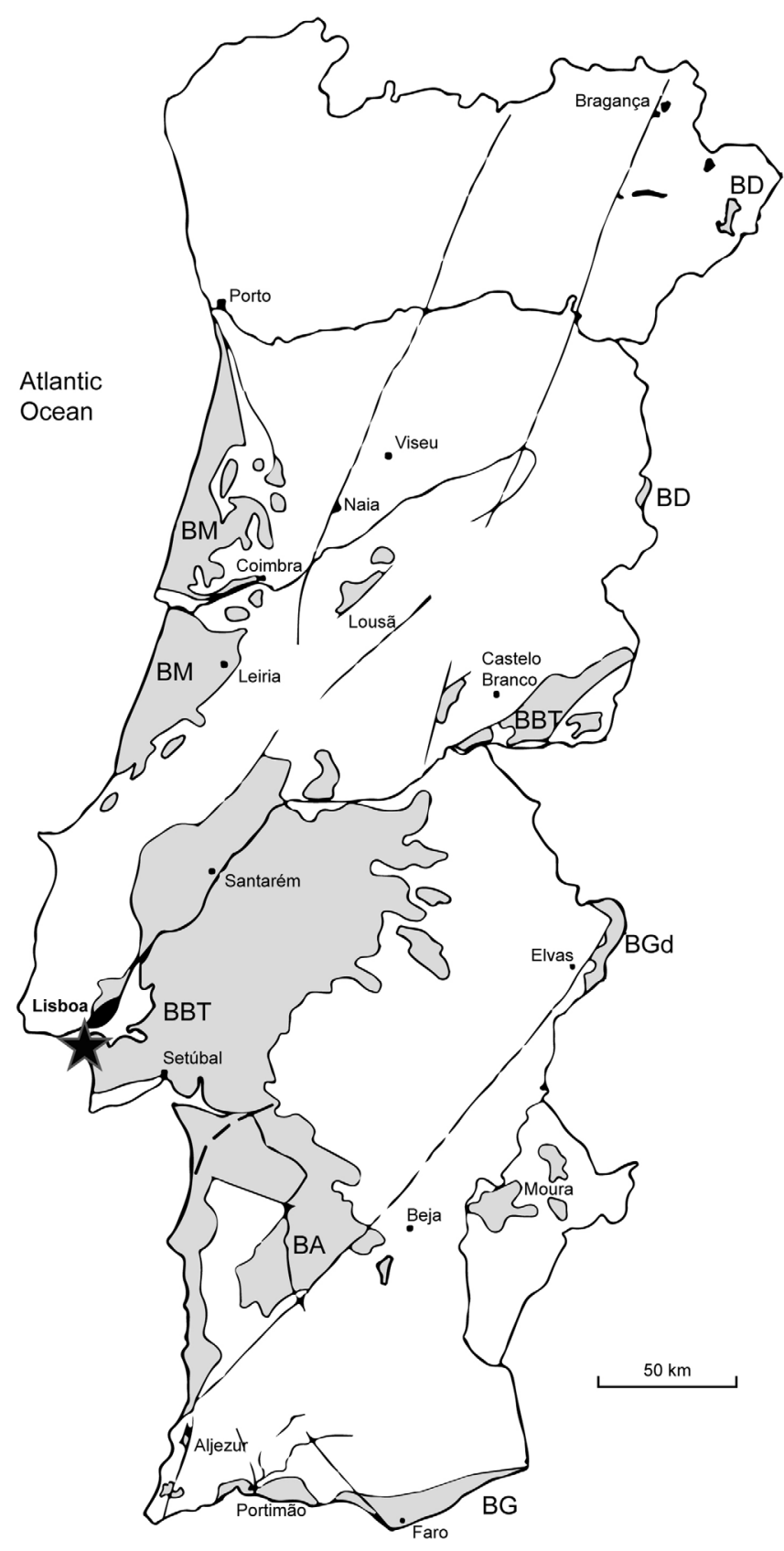

FIGURE 1 Main Portuguese Cenozoic deposits. Black star icon indicates the approximate geographic location of Brielas outcrop, next to Almada-Caparica IC-20 highway, at the geographical coordinates: 38 39'13.6"N, 009 13'30.9'W. BA, Alvalade Basin; BBT, Lower Tagus Basin; BD, Douro Basin; BG, Guadalquivir Basin; BGd, Guadiana Basin; BM, Mondego Basin. Source: Adapted from Legoinha (2001, fig. 2). Scale bar equals $50 \mathrm{~km}$

benthic foraminifera, allow integrated comparison between marine and continental biostratigraphic scales, making possible a highresolution chronostratigraphic framework (Antunes, 2000; Antunes et al., 2000; Antunes, Legoinha, Nascimento, \& Pais, 1996). In addition, isotopic ages provide good chronologic support, namely for the lower and early Middle Miocene. The lithostratigraphic setting has been defined by Cotter (1956). Based on lithological and palaeontological characteristics, Cotter recognized several geological units in this region (from I-Aquitanian to VII-Tortonian, some of them subdivided in $\mathrm{a}, \mathrm{b}$, and $\mathrm{c}$ ), that can be considered as formations in the modern stratigraphic concept (Pais et al., 2012).

The studied chondrichthyan fauna was collected from unconsolidated beds of the Vc unit (Figure 2)-Quinta das Conchas Limestones with Spathic Fossils and Anomia choffati (Cotter, 1956), that crop out at Brielas, on the slopes of the Almada-Caparica IC-20 highway (Setúbal Peninsula). Geographical coordinates: $38^{\circ} 39^{\prime} 13.6^{\prime \prime} \mathrm{N}$, $009^{\circ} 13^{\prime} 30.9^{\prime \prime} \mathrm{W}$ (Figure 1). It consists of a 4-m-thick sequence of yellowish sandy siltite beds, with thin intercalations of fossiliferous calcarenites.

The planktic foraminifera assemblage comprises Globigerina bulloides, G. praebulloides, Globigerinella aequilateralis, Globigerinoides immaturus, G. trilobus, Globorotalia peripheroronda, Orbulina suturalis, Praeorbulina glomerosa, P. transitoria, Globoquadrina dehiscens, and Dentoglobigerina altispira. This association is characteristic of the N9 Biozone (Blow, 1969). Considering the chronological data (Berggren, Kent, Aubry, \& Hardenbol, 1995) admitted for Orbulina suturalis (First Appearance Datum, FAD) and Globorotalia peripheroronda (Last Appearance Datum, LAD), the age of the studied succession ranges between 15.1 and 14.6 Ma.

Both the Vc unit and the following Vla unit-'Xabregas Blue Clays' (Cotter, 1956) record the major transgressive and highstand events of the Lower Tagus Basin Miocene succession. They correspond to the S1 depositional sequence of Antunes et al. (2000), Legoinha (2001), and Pais et al. (2012), as shown in Figure 2. This sequence can be correlated with the third-order eustatic cycle TB 2.4 (Haq, Hardenbol, \& Vail, 1987) and the Lan2/Ser1 sequence (Snedden \& Liu, 2010). Since the base of the Lan2/Ser1 sequence is dated at $14.78 \mathrm{Ma}$ and taking into account the FAD of Orbulina universa, the first occurrence of which is in the Vla unit, we can further limit the age of the studied chondrichthyan fauna to a very short time-span of 14.78-14.73 Ma.

The benthic foraminifera of the Brielas outcrop are dominated by Ammonia and Nonion genera, and by common Lenticulina and Heterolepa. Less frequent are the genera Lagena, Bolivina, Bulimina, and Nodosaria. This assemblage indicates infralittoral environments of sandy bottom and normal salinity and oxygenation. To the top of the section, the presence of Cancris, Cassidulina, and Pullenia denotes increasing water depth (Legoinha, 2001).

\section{3 | MATERIAL AND METHODS}

Due to the present inaccessible state of the Brielas outcrop, the current work focused on the fossil specimens recovered from $93.5 \mathrm{~kg}$ bulk-sample of sediments gathered in 1995 by Ausenda Balbino. The sampling was done by surface picking and removal of the upper $50 \mathrm{~cm}$ of the local Vc unit succession, as suggested by Miguel Telles Antunes, who had previously studied the site (Antunes \& Jonet, 1970). The material was later prepared in the Palaeontology laboratory facilities at the University of Évora, by implementing palaeoichthyological cleaning techniques. 


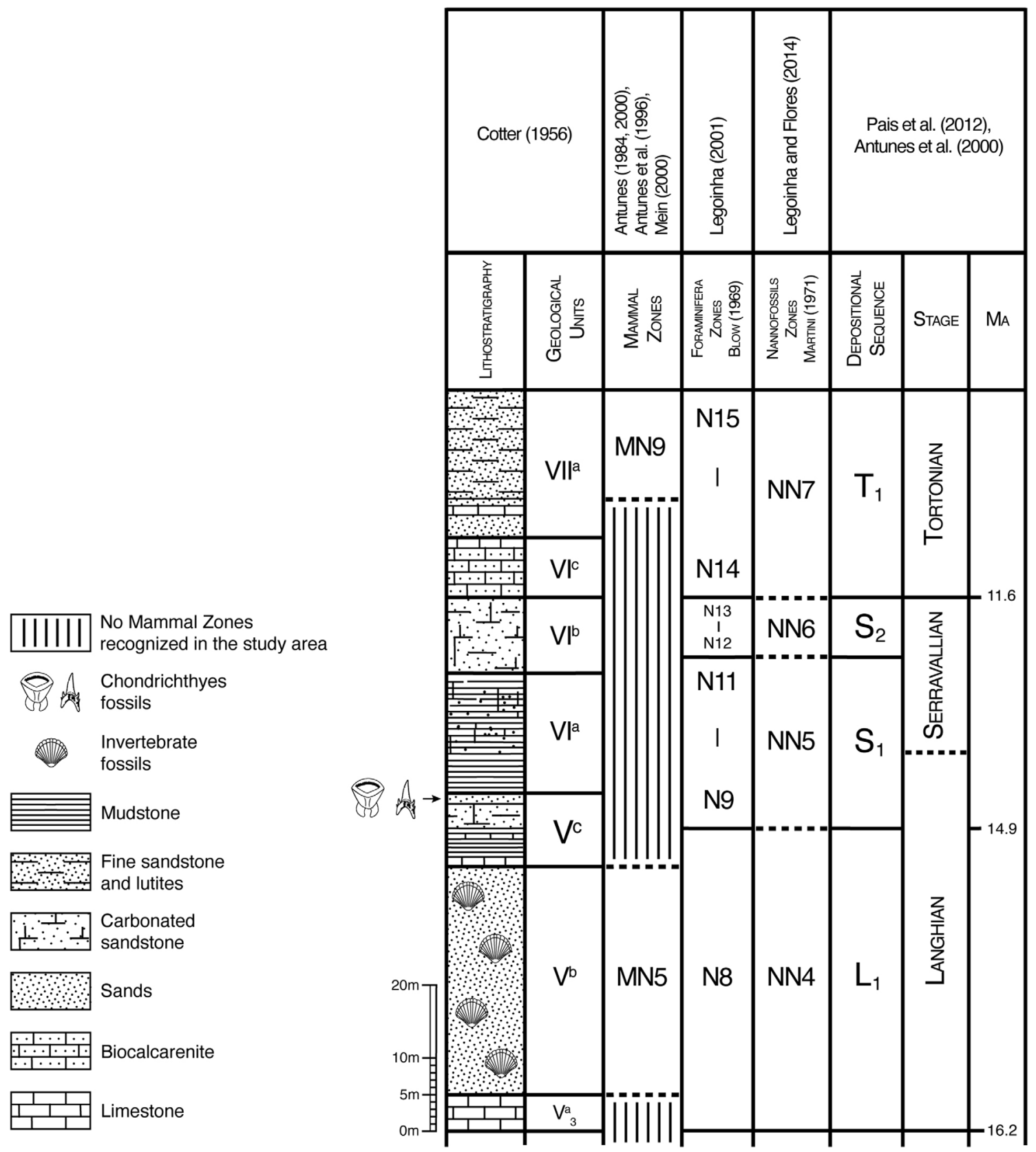

FIGURE 2 Stratigraphic framework for the Middle to Upper Miocene of the Lower Tagus Basin, with the stratigraphic position of the Vc unit. The sampled layer in Brielas fossil site is marked with the representation of Chondrichthyes fossil teeth. L, Langhian; Ma, megaannum; MN, Mammal Neogene zonation; N, foraminifera zone; NN, nannofossil zone; S, Serravalian; T, tortonian. Source: Adapted from Fialho, Balbino, and Antunes (2019, fig. 1a,b). Scale bar in metres

First, the sediments were disaggregated with highly concentrated hydrogen peroxide for a period that varied between 6 and $12 \mathrm{hr}$, depending on their degree of consolidation. The exothermic reaction of the hydrogen peroxide with the organic matter was carefully tempered by adding tap water. Afterwards, the disaggregated sediments were washed thoroughly with running water on three sieves of decreasing mesh size: $2.5,1.0$, and $0.5 \mathrm{~mm}$. Each sieve concentrate was dried in an oven, at a temperature between 50 and $60^{\circ} \mathrm{C}$, and then sorted out under a stereo macroscope. After the description and classification, the material was stored in numbered eppendorf units or clear plastic boxes. The labels follow the reference: UEBR (taxon number).(specimen number). The studied collection is housed and accessible to the scientific community at the Palaeontological Collections of the University of Évora, Évora, Portugal.

The photographic plates (annexes) were prepared using the openaccess software GIMP (2018 version). Depending on their size, the best specimens were registered by a camera mounted on a tripod, a Leica EZ4W Stereo Zoom Microscope Integrated Camera, or a VPSEM-EDS HITACHI 3700N from HERCULES Laboratory (University of Évora) with an acceleration voltage of 10-20 kV. 


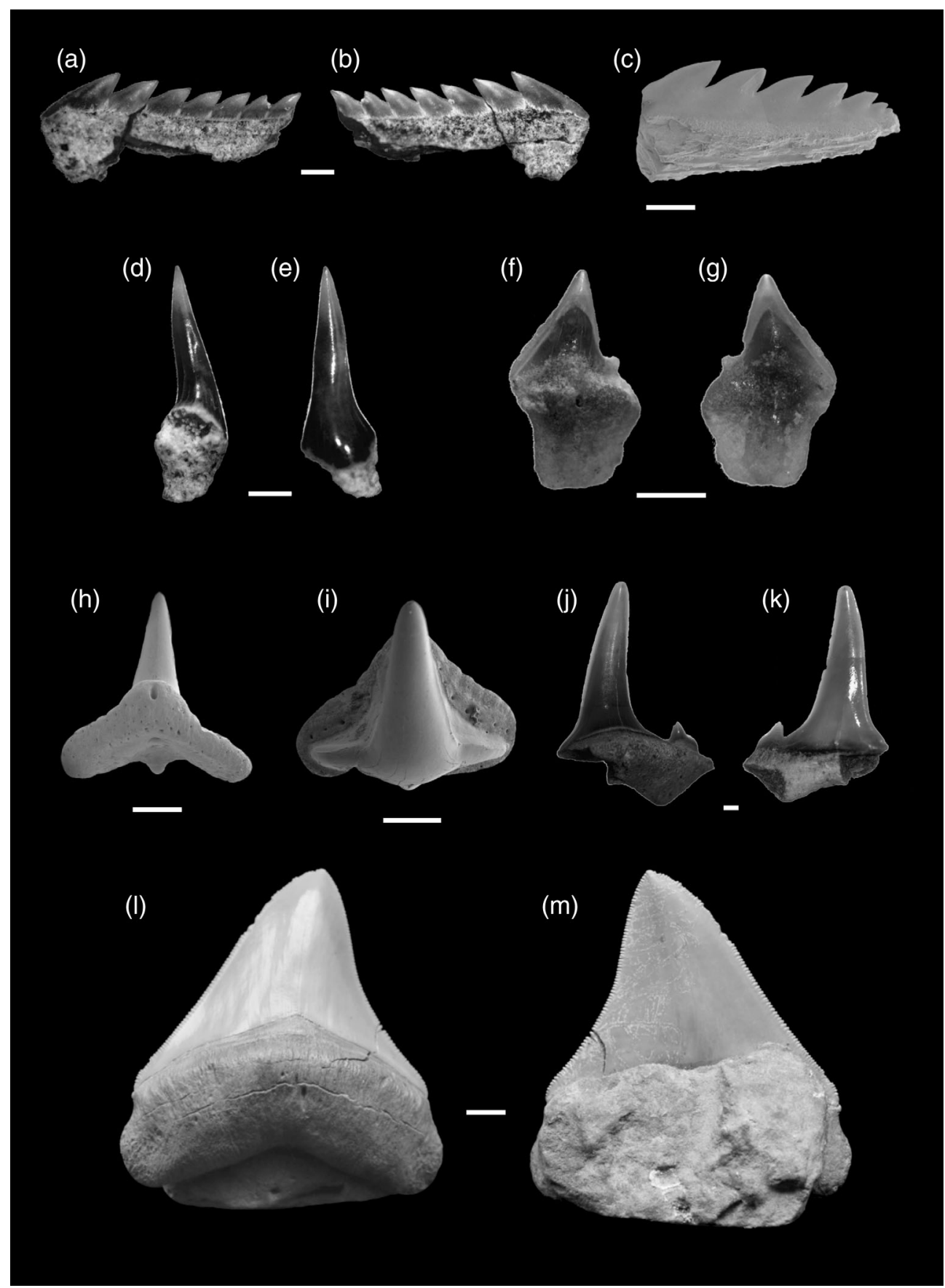

FIGURE $3 \quad(a, b)$ Hexanchus cf. agassizi UEBR_13.1 lower tooth: (a) lingual view; (b) labial view. (c) Hexanchus cf. agassizi UEBR_13.2 lower tooth labial view. (d,e) Hexanchus cf. agassizi UEBR_13.4 upper anterior tooth: (d) lingual view; (e) labial view. $(\mathrm{f}, \mathrm{g})$ Centrophorus cf. granulosus UEBR_14.1 upper tooth: (f) lingual view; (g) labial view. (h,i) Squatina subserrata UEBR_15.1 anterior tooth: (h) lingual view; (i) occlusal view. (j,k) Carcharias acutissimus UEBR_16.1 lateral tooth: (j) lingual view; (k) labial view. (I,m) Otodus (Megaselachus) megalodon UEBR_17.1 lateral tooth: (I) lingual view; $(\mathrm{m})$ labial view. Scale bar equals $1 \mathrm{~mm}$ for (a-k), and $1 \mathrm{~cm}$ for (l-m)

(k)

\section{4}

\section{SYSTEMATIC PALAEONTOLOGY}

For the chondrichthyan material, Compagno's classification (1973) modified by Cappetta (1987, 2012), was adopted. When necessary, updated taxonomy was consulted using the works of Naylor et al. (2012), Pollerspöck and Straube (2019), and Weigmann (2016, 2017). The nomenclature procedures follow Bengtson (1988) and Sigovini, Keppel, and Tagliapietra (2016).

Class Chondrichthyes Huxley, 1880

Subclass Elasmobanchii Bonaparte, 1838

Cohort Euselachii Hay, 1902

Subcohort Neoselachii Compagno, 1977
Superorder Squalomorphii Compagno, 1973

Order Hexanchiformes de Buen, 1926

Family Hexanchidae Gray, 1851

Genus Hexanchus Rafinesque, 1810

Hexanchus cf. agassizi Cappetta, 1976

Figure 3a-e

Material: UEBR_13.1-UEBR_13.4, four isolated teeth.

Description: Fragmented specimens, with average dimensions of $2.92 \mathrm{~mm}$ (total height) by $7.05 \mathrm{~mm}$ (width).

Three lower teeth, elongated mesio-distally, and compressed labio-lingually. The specimen UEBR_13.1 is broken into two parts, as 
shown in Figure 3a,b, and presents an acrocone, followed by six accessory cones. The acrocone is barely more developed than the first accessory cone and has a mesial cutting edge almost straight, with marked indentations in its lower half. The specimen UEBR_13.2 has seven accessory cones; the smaller one near the distal end of the tooth is almost vestigial (Figure 3c). In both specimens, the accessory cones are distally inclined, with decreasing size towards the extremity of the tooth. The most incomplete lower tooth has only two accessory cones.

There is one upper anterior tooth, specimen UEBR_13.4, with only a sigmoidal cusp present. The base of the crown is circular to oval, as observed in lingual (Figure 3d) and labial (Figure 3e) views.

Discussion: According to Cappetta (2012), Hexanchus gigas (Sismonda, 1861), a valid synonymy of the Recent Hexanchus griseus (Bonnaterre, 1788) (Pollerspöck \& Straube, 2019), is the only species of this genus found in Miocene sediments. Therefore, the specimens were compared with lower antero-lateral and median teeth of $\mathrm{H}$. gigas figured by Godfrey (2018, fig. 2.5f,g). However, the acrocone in the lower antero-lateral tooth has a more elongated mesial heel and more accessory cones than the studied material. Indeed, when comparing with another antero-lateral tooth of $\mathrm{H}$. gigas figured by Adnet and Martin (2007, fig. 2), the morphology does not show similarities.

Similarities were found in the morphology of both the acrocone and the accessory cones of an antero-lateral tooth from Hexanchus agassizi (Adnet \& Martin, 2007, fig. 2). The specimens were also compared with lower and upper teeth of $\mathrm{H}$. agassizi figured by Cappetta (2012, fig. 82f), which had an acrocone slightly more developed than the first secondary cone, and shows the same kind of indentations in its lower half as the lower anterior tooth figured in this work. However, since there are still some characters unclear, due to the poor state of conservation of the root, and because we did not find any other Miocene records of this species, the material was referred to as Hexanchus cf. agassizi.

Order Squaliformes Goodrich, 1909

Family Centrophoridae Bleeker, 1859

Genus Centrophorus Müller \& Henle, 1837

Centrophorus cf. granulosus (Bloch \& Schneider, 1801)

Figure $3 f, g$

Material: UEBR_14.1, an isolated tooth.

Description: This small specimen, with $3.33 \mathrm{~mm}$ total height and $2.03 \mathrm{~mm}$ width, is very lingual-labially compressed. In lingual view (Figure $3 f$ ), the crown is triangular, with a mesial cutting edge slightly serrated in its lower half, and a straight distal cutting edge. The crown appears to be distally damaged. The root is higher than the crown, with a concave mesial outline and a larger distal section. There is a distinct lingual protuberance with a marked main foramen.

In the labial view (Figure 3g), the crown shows an apron wider at its base, that grows over the root until it reaches the lower extremity of the root.

Discussion: Despite the difficulty of morphologically distinguishing this genus from Deania Jordan \& Snyder, 1902, it is possible to attribute the specimen to Centrophorus due to the presence of a more elongated root and an apron wider at its base, visible in labial view.

According to Cappetta (2012), at least two Recent species occur in Miocene sites, Centrophorus granulosus, and C. squamosus (Bonnaterre, 1788). The size of the lingual foramen and the shape of the crown does not match the ones from the upper anterior teeth of $C$. squamosus figured by Keyes (1984, figs. 8-14). Similarities were found between the studied specimen and an upper tooth of $C$. granulosus figured by Jost, Kempf and Kälin (2016, fig. 8h), and an almost identical upper tooth studied by Brisswalter (2008, plate 2, fig. 6). The specimen UEBR_14.1 presents an overall shape that falls between those of upper antero-lateral and lateral teeth figured by Cappetta (2012, fig. 98m-0). Hence the attribution to this species.

Order Squatiniformes de Buen, 1926

Family Squatinidae Bonaparte, 1838

Genus Squatina Duméril, 1806

Squatina subserrata (Münster, 1846)

Figure $3 \mathrm{~h}, \mathrm{i}$

Material: UEBR_15.1-UEBR_15.18, 18 isolated teeth.

Description: Small teeth with an average height of $3.26 \mathrm{~mm}$ per $4.07 \mathrm{~mm}$ width. The majority of the material found is massively damaged on the root level.

Of the two anterior teeth recovered, only the specimen UEBR_15.1 is complete (Figure 3h,i). The crown is high and has a triangular outline in the labial view. The cusp is strongly bent lingually and has sharp cutting edges. An expansion of the enameloid is present at the base of the crown, in labial view, forming a well-defined round apron, also visible in the lateral teeth. On each side of the cusp, there is a well-developed heel over the lateral wing of the root, as seen in the occlusal view (Figure 3i). The root in these teeth has a broad basilar face, perpendicular to the crown, with lateral expansions and a pronounced lingual protuberance. Also, in the occlusal view (Figure 3i), right below the crown-root limit of the heels, there are numerous accessory foramina. Whereas, sitting on the basilar face, the root shows a convex outline (Figure $3 \mathrm{~h}$ ). The root is concave, with a flat basal face marked by a triangular depression with its vertex lingually turned. In basal view, on the tip of this depression and directly below the lingual protuberance, it is possible to observe the central foramen.

In the lateral teeth, there is a straight triangular crown, with a cusp slightly bent distally. The cutting edges are also sharp. There is a heel on each side of the cusp; however, these are less pronounced than in anterior teeth. The accessory foramina are also present underneath the crown-root limit in lingual view. The root of lateral teeth is more flattened than in the anterior teeth, with longer lateral wings and a less marked lingual protuberance. In the basal view, the central foramen is also present at the tip of a more subtle and narrow triangular depression.

Discussion: According to Pollerspöck and Straube (2019), the most commonly found species in Miocene sediments is Squatina subserrata. Moreover, indeed, the specimens found are similar to this species in dental morphology. By comparing with the lateral tooth of Squatina 
subserrata figured by Vialle, Adnet and Cappetta (2011, figs. 2-8); lateral and anterior teeth figured by Cappetta (1970, plate 8, figs. 8-14, 8'-11'; Cappetta, 2012, fig. 134a-d), and Antunes and Jonet (1970, plate XVII, fig. 132), we consider that the studied specimens bear enough similarities to justify the attribution to this species.

Superorder Galeomorphii Compagno, 1973

Order Lamniformes Berg, 1937

Family Odontaspididae Müller \& Henle, 1838 (Müller \& Henle, 1841)

Genus CarchariasRafinesque, 1810

Carcharias acutissimus (Agassiz, 1843)

Figure 3j,k

Odontaspis acutissima (Agassiz, 1843): Cappetta, 1970: plate 2, figs. 1-5, 10-12, 14-16.

Carcharias acutissima (Agassiz, 1843): Antunes \& Balbino, 2003: plate 2, figs. $1-5$.

Carcharias acutissima (Agassiz, 1843): Brisswalter, 2008: plate 4, fig. 3.

Carcharias aff. acutissima (Agassiz, 1843): Vialle et al., 2011: figs. 3-1, 3-2.

Material: UEBR_16.1, an isolated tooth.

Description: The specimen found is medium size when compared with other studied fossils, with $15 \mathrm{~mm}$ total height and $10 \mathrm{~mm}$ width, approximately. It is broken on the root level; a lateral cusplet is also missing. It has a high slender main cusp slightly inclined distally and bent towards the rear. In the labial view (Figure 3k), the labial face of the crown is flat. The crown has a broad base that overhangs the root's labial face in the middle of the tooth, which is also visible in labial view. Both cutting edges are sharp, and the distal cusplet is well-developed and almost triangular. In lingual view (Figure 3j), the lingual face of the crown is convex. The lingual face of the root is marked by a prominent lingual protuberance, where a deep groove separates the two well-developed lobes. Only the distal lobe is partly complete, with the mesial one broken off. The main foramen is also visible in the lingual groove.

Discussion: The most common Carcharias species in Miocene sediments is $C$. acutissimus; therefore, we firstly compared the studied specimen with several others of this species. Even with the mesial lobe of the root missing, the specimen matches the morphology of the lateral teeth figured in the works by Cappetta (1970, plate 2, figs. 1-5, 10-12, 14-16), Antunes and Balbino (2003, plate 2, figs. 1-5), Brisswalter (2008, plate 4, fig. 3), and Vialle et al. (2011, figs. 3.1,3.2). Furthermore, it shows, in lingual view, a vertical irregular enameloid ridge, indicated as a typical characteristic of this species by Pollerspöck and Straube (2017), hence the attribution of the tooth to C. acutissimus.

Family Otodontidae Glikman, 1964

Genus Otodus Agassiz, 1838

Subgenus Otodus (Megaselachus) Glikman, 1964

Otodus (Megaselachus) megalodon (Agassiz, 1835)

Figure 31,m
Otodus megalodon (Agassiz, 1835): Goedert et al., 2017: fig. 2g.

Megaselachus megalodon (Agassiz in Charlesworth, 1837): Antunes, Legoinha, \& Balbino, 2015: figs. 1-4.

Carcharocles megalodon (Agassiz, 1843): Carrillo-Briceño et al., 2016: figs. 3.12-21.

Carcharocles megalodon (Agassiz, 1843): Perez et al., 2017: figs. 4.1-5.

Carcharocles megalodon (Agassiz, 1843): D'Anastasio, LópezLázaro, \& Viciano, 2018: figs. 1-3.

Carcharocles megalodon (Agassiz, 1843): Godfrey, 2018: figs. 1.4b, 2.13c,d, 2.14a-g.

Material: UEBR_17.1, an isolated tooth.

Description: A single lateral tooth was found in excellent preservation conditions. It has a total height of 82 and $77 \mathrm{~mm}$ width, approximately.

In lingual view (Figure 3l), we can observe a broad triangular crown, slightly bent distally. Regular and small serrations mark the cutting edges. It is possible to see the notches separating the serrations. The mesial cutting edge is almost straight, whereas the distal cutting edge is concave. The lingual face of the crown is very convex, and a short neck marks it. The root is massive and thick, with a well-marked lingual protuberance, where we can observe the central foramen. There are smaller foramina near the limit crown-root, in lingual view. The root is divided into two short and straight lobes with rounded extremities. In the lingual view, the basal outline of the root is concave.

In labial view (Figure $3 \mathrm{~m}$ ), the labial face of the crown is slightly convex. The matrix almost entirely covers the labial face of the root. It was left there to preserve the integrity of the tooth, which is fractured in the distal end.

Discussion: According to Cappetta (2012), the genus Otodus is divided into three subgenera: Otodus (Otodus) Agassiz, 1838; Otodus (Carcharocles) Jordan \& Hannibal, 1923; Otodus (Megaselachus). As the specimen does not exhibit lateral cusplets, characteristic of the first two subgenera (Cappetta, 2012), we can attribute it to the subgenus Otodus (Megaselachus). The database by Pollerspöck and Straube (2019) indicates the existence of only two species in this subgenus: O. (M.) chubutensis (Ameghino, 1901) and O. (M.) megalodon (Agassiz, 1835). Due to its size, with $80 \mathrm{~mm}$ height and $70 \mathrm{~mm}$ width, approximately, larger than the teeth of O. (M.) chubutensis (Laurito, 2015), the specimen was compared only with specimens of $O$. (M.) megalodon and its synonymies.

The studied tooth is similar in shape, size and overall morphology to the lateral teeth of Otodus (Megaselachus) megalodon figured by Maisch, Becker, and Chamberlain (2018, figs. 4k,l, 6a) and Cappetta (2012, fig. 210a-f); Carcharocles megalodon figured by D'Anastasio et al. (2018, figs. 1-3), Perez et al. (2017, figs. 4.1-5), Carrillo-Briceño et al. (2016, fig. 3.12-21) and Godfrey (2018: figs. 1.4b, 2.13c,d, 2.14a-g); Otodus megalodon figured by Goedert et al. (2017, fig. 2g); and Megaselachus megalodon figured by Antunes et al. (2015, figs. 1-4). Hence the attribution to this species.

Family Alopiidae Bonaparte, 1838

Genus Alopias Rafinesque, 1810

Alopias sp.

Figure $4 a-d$ 
FIGURE 4 (a,b) Alopias sp. UEBR_18.1 anterior tooth: (a) basal view; (b) labial view. (c,d) Alopias sp. UEBR_18.2 commissural tooth: (c) lingual view; (d) labial view. (e,f) Megascyliorhinus sp. UEBR_19.1 isolated tooth: (e) lingual view; (f) labial view. (g,h) Pachyscyllium dachiardii UEBR_20.1 very lateral tooth: (g) lingual view; (h) labial view. (i,j) Pachyscyllium dachiardii UEBR_20.2 anterior tooth: (i) lingual view; (j) occlusal view. (k-m) Pachyscyllium dachiardii UEBR_20.3 lateral tooth: (k) lingual view; (I) labial view; (m) occlusal view. Scale bar equals $1 \mathrm{~mm}$

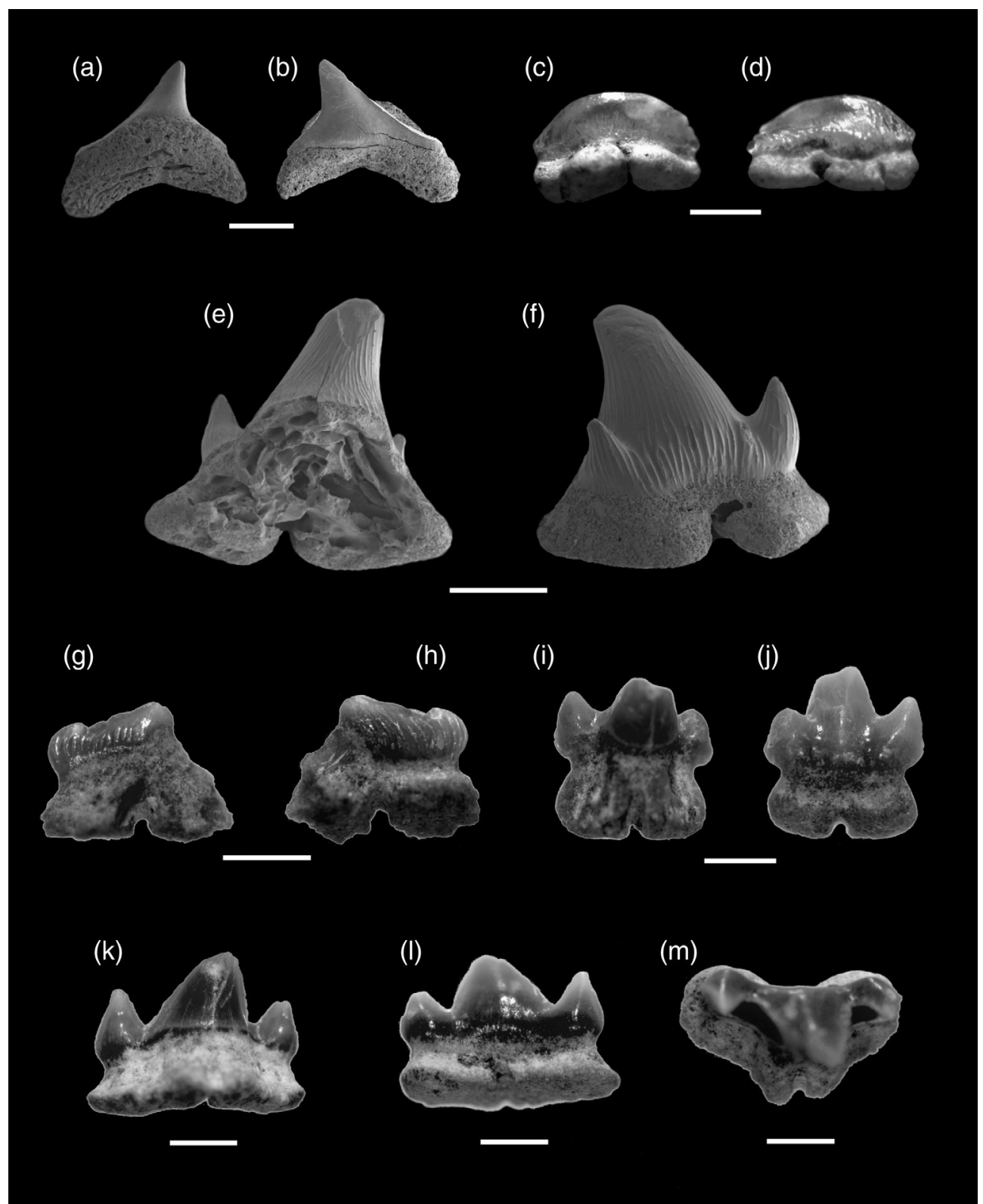

Material: UEBR_18.1-UEBR_18.7, 7 isolated teeth.

Description: The teeth are in a good preservation state. With average dimensions of $2.68 \mathrm{~mm}$ total height per $2.99 \mathrm{~mm}$ width; these are small specimens.

The anterior teeth have, in labial view (Figure 4b), a triangular crown lingually bent and a short cusp slightly distally inclined. The cutting edges are sharp and continue in the lateral heels. Divided into two well-developed elongated lobes, the root shows a rather flat labial face, with a broad arched outline. Only the cusp is noticeable in basal view. The root has a flat basal face and lacks a furrow (Figure 4a).

The specimen UEBR_18.2 appears to be a very well-preserved commissural tooth. It is smaller than the other specimens. In the lingual view (Figure 4c), it is possible to observe the crown made of a single and curved blade. The root is divided by a deep furrow in two lobes of different sizes. In labial view (Figure 4d), there are vertical ridges in the base of the crown. In occlusal view, it is clear that the crown blade is quite compressed lingual-labially.

Discussion: By comparing the studied material with anterior and lateral teeth of Alopias crochardi Ward, 1978, figured by Carlsen and Cuny (2014, fig. 6a-f), we observed that although the crown morphology resembles the one of lateral teeth, the specimens differ in showing lower crowns and no lingual furrow.

On another hand, although the overall morphology of the teeth resembles the one of Alopias cf. superciliosus (Lowe, 1841), figured by Antunes and Jonet (1970, plate VII, figs. 23-25; plate VIII, figs. 27-29, 40,41), Antunes and Balbino (2003, plate 3, fig. 2) and Godfrey (2018, fig. 2.18d), the cusp of the specimens depicted in these works is higher and straighter, and the teeth's root is marked by a furrow, absent in the studied material. 
There are some similarities with the anterior and lateral specimens of A. vulpinus (Bonnaterre, 1788) figured by Cappetta (2012, fig. 222c-e), Alopias cf. vulpinus figured by Antunes and Jonet (1970, plate VII, fig. 26; plate VIII, figs. 30-39), Cicimurri and Knight (2009, fig. 4a,b), Godfrey (2018: fig. 2.18a-c) and Alopias aff. vulpinus figured by Brisswalter (2008, plate 3 , fig. 12). However, the cusp in the analysed teeth is more slender. The commissural tooth was compared to teeth of the same position of $A$. vulpinus (Cappetta, 2012, fig. $222 f-k)$, but the specimens are very different.

We think that the morphology of the studied material is somewhat between $A$. superciliosus and A. vulpinus. Therefore, in the light of the current knowledge, it has been left in open nomenclature.

Order Carcharhiniformes Compagno, 1973

Family Scyliorhinidae Gill, 1862

Subfamily Megascyliorhininae Pfeil, 1984

Genus Megascyliorhinus Cappetta \& Ward, 1977

Megascyliorhinus sp.

Figure $4 \mathrm{e}, \mathrm{f}$

Material: UEBR_19.1, an isolated tooth.

Description: With $3.33 \mathrm{~mm}$ total height and $3.55 \mathrm{~mm}$ width, this small specimen has a severely damaged root, as seen in the lingual view (Figure 4e). The crown has a main cusp lingually bent and with the tip chipped off. The lingual face of the crown is concave. A pair of conical lateral cusplets flank the cusp, clearly visible in labial view (Figure 4f). Notice the strong folding present from the bottom to the apex of the main cusp and lateral cusplets, visible in both lingual and labial views. The root is high and broader, and although the lingual face of the root is broken, it is still possible to observe a central groove dividing the two large lobes. The root has a flat basal face.

Discussion: Although the tooth is similar to the antero-lateral teeth of Megascyliorhinus miocaenicus depicted by Antunes and Balbino (2004, fig. 3e-g) and Rhincodon miocaenicus figured by Antunes and Jonet (1970, plate IX, figs. 42-44), the crown's vertical folds are more marked in the specimen than in this species dental morphology.

By comparing the specimen with antero-lateral and lateral teeth of M. cooperi featured by Cappetta (2012, fig. 244), we find they have the massive root and strong folds in common. The studied fossil tooth has a much lower crown with lateral cusplets also present, but it could belong to a smaller shark of this species or be a tooth of a more lateral position in the mouth. Despite this, because there is only one tooth in the sample in a poor state of preservation, we decided it was best to leave it in open nomenclature.

Subfamily Premontreinae Cappetta, 1992

Genus Pachyscyllium Reinecke, Moths, Grant, \& Breitkreuz, 2005

Pachyscyllium dachiardii (Lawley, 1876)

Figure 4g-m

Scyllium d'achiardii Lawley, 1876 (original description).

Premontreia (Oxyscyllium) cf. dachiardii (Lawley, 1876): García et al., 2011: fig. 4.
Material: UEBR_20.1-UEBR_20.29, 29 isolated teeth.

Description: Five complete and 24 broken teeth were found. With average dimensions of $2.64 \mathrm{~mm}$ high per $2.66 \mathrm{~mm}$ wide, approximately, these small specimens have a main cusp rather high and lingually inclined, with smooth cutting edges. There are one or two pairs of lateral denticles well separated from the main cusp. The lingual face of the crown is convex. Also, in lingual view, it is possible to observe a robust and low root, with a deep median furrow in which the main foramen opens lingually. The basal face of the root is flat. In labial view, some specimens present vertical ridges at the base of the crown.

The anterior teeth, like the specimen UEBR_20.2 (Figure 4i,j), are bulkier than the lateral ones, represented by specimen UEBR_20.1 (Figure $4 \mathrm{k}, \mathrm{m}$ ), and less elongated.

Specimen UEBR_20.1 appears to be a very lateral broken tooth. Smaller in size, it has a blade crown compressed lingual-labially with what seems to be a vestigial lateral cusplet. Vertical ridges mark the crown surface in both lingual and labial views (Figure 4g,h), from the bottom to the top of the crown.

Discussion: Both the main cusp and the lateral denticles are lower than the ones found in specimens of Premontreia (Syn. Pachyscyllium) distans (Probst, 1879) figured by Jost et al. (2016, fig. 8c).

When compared with specimens of a common Neogene fossil species, Pachyscyllium dachiardii, we found the morphology of this species to be very similar. $P$. dachiardii was previously described for the Miocene sediments of the Portuguese Alvalade Basin (Sta. Margarida, Esbarrondadoiro, and Vale de Zebro sites) by Antunes and Balbino (2003). The morphology of the crown and root of the studied specimens is similar to the antero-lateral and lateral teeth of P. dachiardii, as figured by Brisswalter (2008, plate 5, fig. 1; plate 10, fig. 3), Schultz, Brzobohatý and Kroupa (2010, plate 2, figs. 5,6); Pachyscyllium aff. dachiardii, as figured by Vialle et al. (2011, figs. 3,8,9), and Premontreia (Oxyscyllium) cf. dachiardii featured by García et al. (2011, fig. 4). We also found the morphology of the lateral and very lateral studied teeth in the correspondent teeth of $P$. dachiardii figured by Cappetta (2012, fig. 247). Therefore, the studied material was attributed to this species.

Genus Scyliorhinus de Blainville, 1816

Scyliorhinus sp.

Figure 5a,b

Material: UEBR_21.1-UEBR_21.21, 21 isolated teeth.

Description: With an average width of $1.86 \mathrm{~mm}$, approximately, most of these small specimens have a broken or eroded root.

The anterior or antero-lateral teeth specimens are considerably laterally compressed in comparison with the lateral teeth specimens. The labial face of the crown clearly overhangs the root labial face. In labial view, some teeth present strong vertical ridges, in the base of the labial face of the crown, near the limit crown-root. In lingual view, the main cusp of the crown is triangular, with a broad base and distally inclined (Figure 5b). The cusp cutting edges are sharp to smooth, depending on the tooth. In some teeth, there are one to two pairs of 
FIGURE 5 (a) Scyliorhinus sp. UEBR_21.1 lateral tooth lingual view. (b) Scyliorhinus sp. UEBR_21.2 anterior tooth lingual view. (c,d) Galeorhinus goncalvesi UEBR_22.1 symphyseal tooth: (c) lingual view; (d) labial view. (e) Galeorhinus goncalvesi UEBR_22.2 anterior tooth lingual view. $(f, g)$ lago angustidens UEBR_23.1 lateral tooth: (f) lingual view; (g) labial view. (h,i) Chaenogaleusaffinis UEBR_24.1 upper antero-lateral tooth:

(h) lingual view; (i) labial view. (j) Chaenogaleusaffinis UEBR_24.2 lower lateral tooth lingual view. (k,l) Chaenogaleusaffinis UEBR_24.3 upper lateral tooth: (k) lingual view; (I) labial view. (m) Chaenogaleusaffinis UEBR_24.4 lower anterior tooth lingual view. Scale bar equals $1 \mathrm{~mm}$

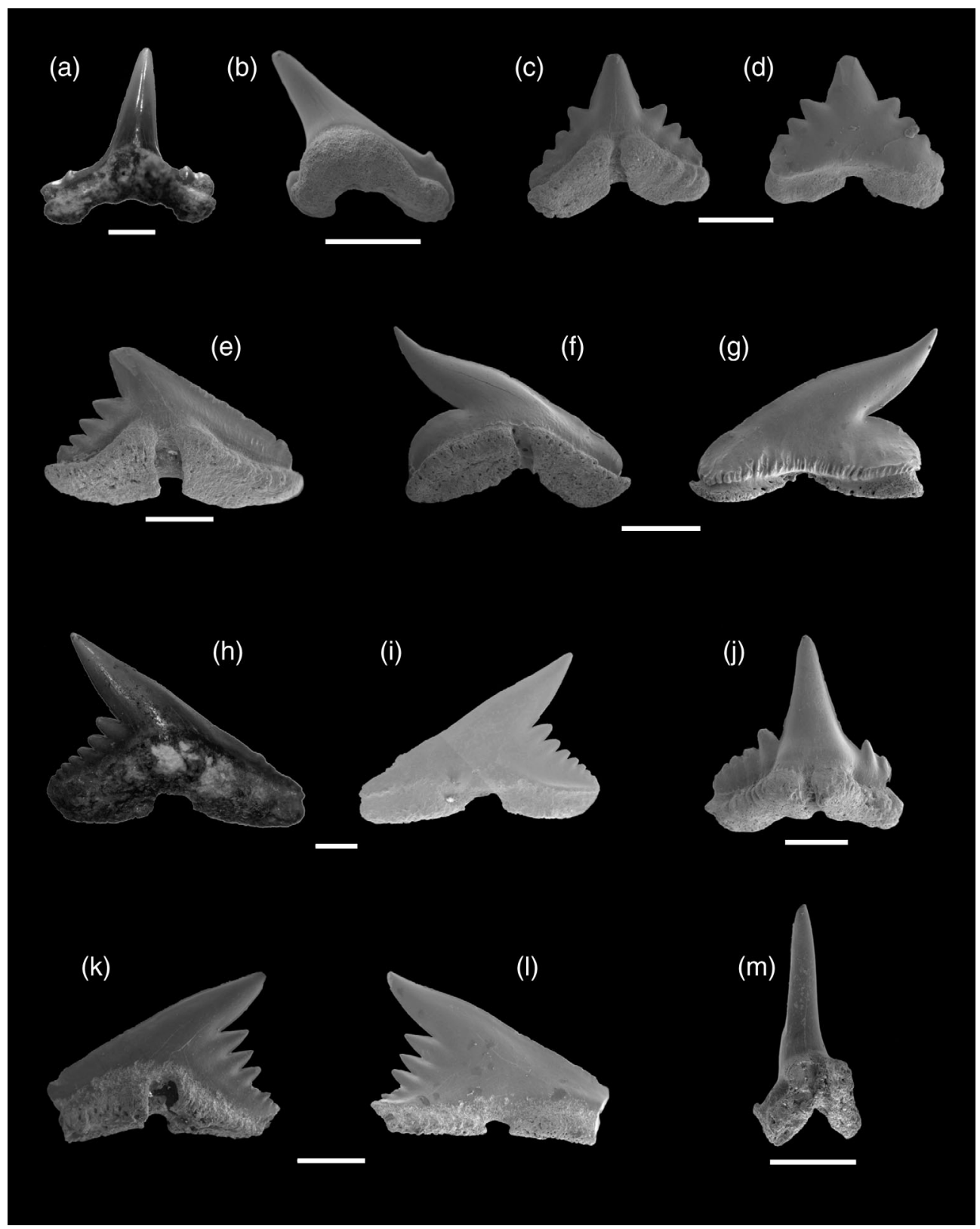

smooth and short lateral cusplets. The lingual face of the crown is concave; therefore, the cusp is also lingually inclined. In the lingual view, the root has a prominent lingual protuberance, and it is divided into two lobes of different sizes. The distal lobe is smaller than the mesial lobe. The root has a flat basal face.

The lateral specimens are laterally elongated. The labial face of the crown overhangs the root and bears strong vertical ridges near the limit crown-root. In labial view, it is possible to observe the pairs of lateral cusplets, smooth and short. In lingual view, the main cusp is almost straight and less lingually inclined, with a triangular shape and broad base. The root has a flat basal face. It presents, in lingual view, a pronounced lingual protuberance, and its lobes are longer and more similar in size and shape (Figure 5a).

Discussion: The studied lateral specimens are less bulky in comparison with the lateral teeth of Scyliorhinus ambliatlanticus
Laurito Mora, 1999 (plate 8, fig. 2a-e). All fossil specimens found to have crowns with a broader base, differing from lateral and anterior teeth of S. joleaudi Cappetta, 1970 (plate 10, figs. 1-17), Antunes and Balbino (2004, figs. 3h-m) and Vialle et al. (2011, figs. $3,10,11$ ).

However, there are some similarities between the studied teeth and the ones from anterior and antero-lateral teeth of $S$. biformis Reinecke, 2014 (figs. 2, 3) and Pollerspöck and Straube (2017, figs. 5.1-7), as well as with anterior teeth of recent specimens of S. canicula (Linnaeus, 1758) figured by Cappetta (2012, fig. 252K-N); the morphology of the root lobes and the lateral denticles are very similar. However, the studied specimens do not have the ornamentation on the lingual face of the crown, as shown in these species. The material was also compared to specimens of $S$. fossilis (Leriche, 1927) figured by Antunes, Jonet and Nascimento (1981, plate 3, fig. 12) and 
Jost et al. (2016, fig. 8d), however the angle between the root lobes in the studied material is wider than the one present on this species.

Therefore, due to the lack of more complete material, we assign the specimens only to the Scyliorhinus genus, leaving it in open nomenclature until new material is found.

Family Triakidae Gray, 1851

Genus Galeorhinus de Blainville, 1816

Galeorhinus goncalvesi Antunes, Balbino, \& Cappetta, 1999b

Figure $5 \mathrm{c}-\mathrm{e}$

Galeorhinus gonçalvesi Antunes, Balbino, \& Cappetta, 1999b: Antunes \& Balbino, 2004: fig. 5a-c,e-g.

Material: UEBR_22.1-UEBR_22.35, 35 isolated teeth.

Description: Small-sized specimens, mostly in good preservation conditions, with an average height of approximately $2.20 \mathrm{~mm}$ and width of $3.38 \mathrm{~mm}$.

There are several symphyseal teeth like UEBR_22.1 in the sample, with an average size of $2.28 \mathrm{~mm}$ high per $2.26 \mathrm{~mm}$ wide. In labial view, their crown's cusp has a triangular shape. It is wide and straight, almost symmetrical in some specimens (Figure $5 \mathrm{~d}$ ). The cutting edges have small denticles. In less eroded teeth it is possible to observe, in labial view, the labial face of the crown overhanging the root. In lingual view (Figure $5 c$ ), the root presents a lingual protuberance with a deep and rather wide sulcus.

The anterior teeth are wider, with a triangular crown inclined to the commissure. The mesial cutting edge is smooth and slightly convex or concave, depending on the specimen, indistinguishable from the mesial heel, and can have low basal denticles. The distal cutting edge is also slightly convex, distinct from the distal heel, which bears up to five cusplets of decreasing size towards the root. In labial view, the labial base of the crown presents a rather straight bulge, overhanging the root. In lingual view, the root is not thick and has two lobes. A lingual protuberance marks it with a broad and deep sulcus (Figure 5e).

Discussion: Galeorhinus goncalvesi was first described from the material studied by A. Balbino, as part of her PhD thesis (Balbino, 1995). The teeth found and analysed in the current work were compared with specimens of this species and the original description by Antunes et al. (1999b, plate 1, figs. 1-7), also figured by Ward and Galea Bonavia (2001, plate 1, figs. g-h) and Brisswalter (2008, plate 5, figs. 5-7).

Although, in Portugal, this species is only known from the uppermost Miocene, both the crown and root morphologies show high similarities with the studied material, and the symphyseal teeth are almost identical to the ones figured by Brisswalter (2008). Hence the attribution of the material to this species.

Genus lago Compagno \& Springer, 1971

lago angustidens (Cappetta, 1973)

Figure $5 f, g$

Triakis angustidens (Cappetta, 1973): plate 12, figs. 23-32 (original description).
Material: UEBR_23.1-UEBR_23.6, 6 isolated teeth.

Description: Well-preserved specimens, of small dimensions, with an average of $2.15 \mathrm{~mm}$ high per $2.90 \mathrm{~mm}$ wide, approximately.

The lateral teeth are wider than high. The crown is inclined to the commissure of the tooth. The cusp is elongated and has a sigmoidal contour, with the apex bent backwards. Whereas the mesial cutting edge is fused with the mesial heel, the distal cutting edge is distinctively separated of its correspondent heel by a pronounced notch. In labial view, the labial face of the crown clearly overhangs the root with a bulge marked by small vertical folds (Figure $5 \mathrm{~g}$ ). In lingual view, the root has two lobes of different sizes and a flat basal face. It is marked by the presence of a lingual protuberance divided by a deep sulcus where the main foramen opens (Figure 5f).

Discussion: The specimens were compared with a lateral tooth of lago carlaluisai Leder, 2013 (plate 2, figs. 1-27); however, this species presents a slimmer crown. The morphology of the studied material is more similar to the one of lateral teeth of lago angustidens as figured by Cappetta (2012, fig. 276), Pollerspöck and Beaury (2014, plate 2, fig. 6) and Brisswalter (2008, plate 5, figs. 8-10), sharing the same sigmoidal mesial cutting edge contour and the vertical ridges in the base of the labial face of the crown, hence the attribution to this species.

Family Hemigaleidae Hasse, 1879

Genus Chaenogaleus Gill, 1862

Chaenogaleus affinis (Probst, 1878)

Figure $5 \mathrm{~h}-\mathrm{m}$

Galeorhinus affinis (Probst, 1878): Antunes \& Jonet, 1970, plate XII, figs. 75-79.

Material: UEBR_24.1-UEBR_24.112, 112 isolated teeth.

Description: The specimens found have, on average, $2.88 \mathrm{~mm}$ total height and $3.40 \mathrm{~mm}$ width, approximately. Due to the presence of heterodonty in the dentition of Chaenogaleus, the whole sample may be divided into upper and lower teeth.

The upper teeth are characterized by a high crown, with a broad base. The main cusp is distally inclined, more so in lateral teeth (Figure $5 k, l)$ than in anterior ones (Figure $5 h-l)$. The labial face of the crown is flat and does not have a basal bead overhanging the root. The mesial cutting edge is long, smooth, and slightly convex. The distal cutting edge is straight and shorter, clearly marked by a notch separating the distal heel, which has six distal cusplets or serrations of decreasing size towards the rear of the tooth. The lingual face of the crown is slightly convex. The root has two well-developed lobes and is marked by a lingual protuberance, cut deeply by a furrow where the main foramen opens.

The lower anterior teeth like the specimen UEBR_24.4 (Figure $5 \mathrm{~m}$ ) have a straight and slender cusp and are mesio-distally compressed. There may be mesial and distal heels with or without a small lateral denticle, depending on the specimens. The lower lateral teeth (Figure 5j) are broader and have several distal denticles, and only a few mesial lateral denticles. In labial view, the labial face of the crown overhangs the root with a pronounced bulge. In lingual view, the root 
FIGURE 6 (a,b) Hemipristis serra UEBR_25.1 lateral tooth: (a) lingual view; (b) labial view. (c,d) Galeocerdo aduncus UEBR_26.1 lateral tooth: (c) lingual view; (d) labial view. (e,f) Scoliodon sp. UEBR_27.2 antero-lateral tooth: (e) lingual view; (f) labial view. (g,h) Rhizoprionodon ficheuri UEBR_28.1 lateral tooth: (g) lingual view; (h) labial view. $(\mathrm{i}, \mathrm{j})$ Carcharhinus priscus UEBR_29.1 upper tooth: (i) lingual view; (j) labial view. (k,l) Carcharhinus priscus UEBR_29.2 lower tooth: (k) lingual view: (I) labial view. Scale bar equals $1 \mathrm{~mm}$

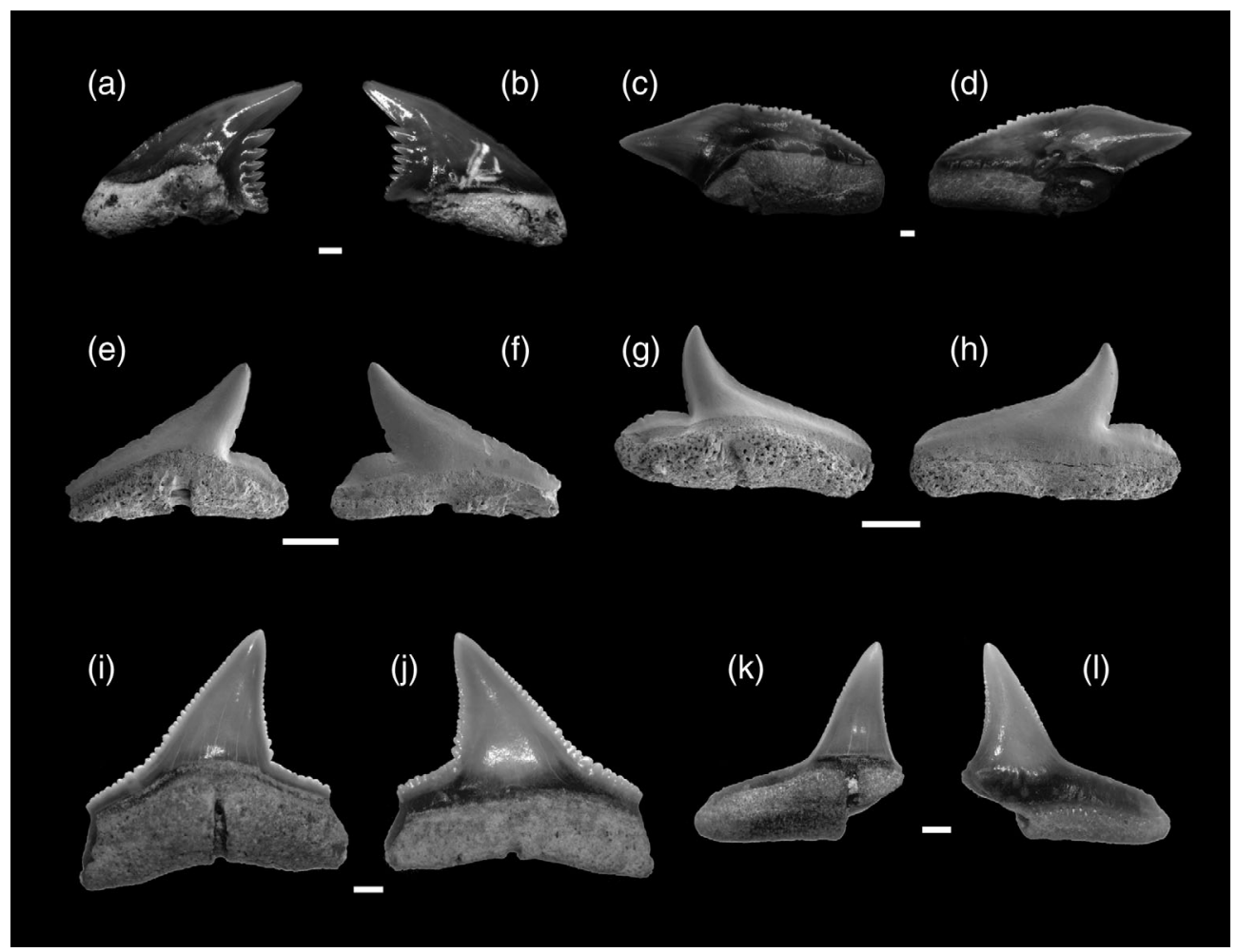

is massive and also divided into two lobes by a deep furrow, where the main foramen may be observed (Figure $5 \mathrm{~m}$ ).

Discussion: Similar to what was experienced by other authors like Brisswalter (2008), the upper teeth resemble those of the Galeorhinus genus, creating some confusion. However, it is possible to distinguish between their dental morphologies. Chaenogaleus teeth do not have a bead at the base of the labial face of the crown, overhanging the root, hence the attribution of the material to this genus. According to the information available in the database by Pollerspöck and Straube (2019), Chaenogaleusaffinis is the only fossil species of this genus, and it has already been accounted for in the Lisbon's Miocene by Antunes and Jonet (1970).

The studied material was compared with upper and lower, antero-lateral and lateral, specimens of $C$. affinis figured by Cappetta (2012, fig. 279a-f); an upper tooth studied by Jost et al. (2016, fig. 8b), and upper lateral teeth figured by Schultz et al. (2010, plate 2, figs. 7, 8). Both morphologies of upper and lower fossil teeth are very similar to those represented in those works, with the same type of dignathic heterodonty and dentition cutting-clutching subtype. Therefore, we attributed this material to Chaenogaleus affinis.

Genus Hemipristis Agassiz, 1835

Hemipristisserra Agassiz, 1835

Figure 6a,b

Material: UEBR_25.1, an isolated tooth.

Description: A fragmented single tooth was recovered, $8 \mathrm{~mm}$ high, and $7 \mathrm{~mm}$ wide, approximately.
The crown in triangular and distally inclined, with the tip, slightly bent backward. In the profile view, it is possible to observe that the lingual face of the crown is convex, whereas the labial face of the crown is almost flat (Figure 6a,b). In lingual view, the lingual protuberance of the root is still present, though very eroded (Figure 6a).

The distal cutting edge is smooth in its first third of length, with a concave outline, bearing nine smaller denticles in the last two thirds. These denticles have decreasing size towards the commissure of the tooth, and the first one is small, in comparison with the main cusp's apex. The mesial cutting edge has a convex outline, and it is smooth for almost all its length with the presence of three vestigial denticles or a smooth serration near the root.

From the remains of the root is possible to infer that it would be bilobed and low, with short and thin lobes.

Discussion: All three fossil species of Hemipristis can be found in Miocene sediments (Pollerspöck \& Straube, 2019): Hemipristis curvatus Dames, 1883; Hemipristis serra; Hemipristis unidenticulata Ralte, Tiwari, Lalchawimawii, \& Malsawma, 2011. H. serra is the most commonly found species of the three.

Although the presence of denticles of decreasing size is mostly observed in the teeth of $\mathrm{H}$. serra, as a distinct characteristic, as seen in an upper lateral tooth of this species depicted by Cappetta (2012, fig. 279g-i) and Antunes and Jonet (1970, plate XII, fig. 67), there are also specimens of this species where the denticles are almost absent from the mesial cutting edge. This is seen in a specimen of $\mathrm{H}$. serra figured by Carrillo-Briceño et al. (2016, figs. 4, 8-13), similar to the studied tooth. The tip of the crown in this specimen, however, is entirely distally bent (Carrillo-Briceño et al., 2016, figs. 4, 8), differing from the slightly bent backwards tip as seen in the studied specimen. 
Observing the anterior, antero-lateral and lateral teeth morphology of H. curvatus Dames (1883, plate III, figs. 7-8) also figured by Underwood et al. (2011, fig. 5b,c), and its synonymy $H$. wyattdurhami White, 1956, figured by Case (1980, plate 5, figs. 3-5), and Westgate (1984, fig. 3d), we recognize the same almost complete absence of denticles on the mesial cutting edge, with a few denticles in some specimens, such as in the studied specimen. The teeth of H. unidenticulata Ralte et al. (2011, plate 3, fig. 7a-c) are dissimilar to the studied specimen, with not only denticles present in both cutting edges, but also an isosceles triangular crown.

Despite the similarities found between the studied fossil tooth and the teeth of $H$. curvatus, since this species has not been previously found in the Langhian, there is only one tooth reported in the material studied to compare, and the main differentiating characteristic, the absence of decreasing size denticles in the mesial cutting edge, has also been seen in some specimens of $\mathrm{H}$. serra, we decided to attribute the specimen to Hemipristis serra.

Family Carcharhinidae Jordan \& Evermann, 1896

Genus Galeocerdo Müller \& Henle 1838

Galeocerdo aduncus Agassiz, 1835

Figure $6 c, d$

Material: UEBR_26.1, an isolated tooth.

Description: Only a fragmentary specimen, with $19 \mathrm{~mm}$ of height per $11 \mathrm{~mm}$ of width, was recovered. It is a lateral tooth, with the crown strongly distally inclined. A straight serrated distal cutting edge, broken at the base, with the root missing. The mesial cutting edge is strongly convex, and it is entirely covered by a complex serration, in which the denticles are also serrated. The lingual face of the tooth is convex, whereas the labial face is strongly concave. In lingual view, the root is well-developed and bilobed, with a not very pronounced lingual protuberance. The lingual limit between the crown and the root is marked by a sulcus, more subtle in the distal section (Figure 6c). In labial view, the crown slightly overhangs the root (Figure 6d).

Discussion: The specimen was compared with lateral teeth of Galeocerdo cuvier (Péron \& Lesueur in Lesueur, 1822) (Cappetta, 2012, fig. 281a-d; Maisch et al., 2018, fig. 5q,r), which differ from the studied specimen, with a main cusp with a broader base and less pronounced crown-root limit in both lingual and labial views.

It is by comparing with teeth of $G$. aduncus that we find a higher level of similarity. The lateral teeth figured by Case (1980, plate 5, fig. 8), Brisswalter (2008, plate 6, fig. 7), Carrillo-Briceño et al. (2016, figs. 4, 14-18) and Maisch et al. (2018, fig. 5o,p), match the overall morphology of the studied tooth. Antunes and Balbino (2004, fig. 6e) also refer to G. aduncus exemplars from Maryland's Miocene, which had a more straight and acute crown, much like the current fossil, and that difference could be due to the position of the teeth or the variability. Therefore, we attribute the specimen to Galeocerdo aduncus.

Genus Scoliodon Müller \& Henle, 1837

Scoliodon sp.

Figure $6 e, f$
Material: UEBR_27.1-UEBR_27.35, 35 isolated teeth.

Description: Teeth poorly preserved. Most specimens have a broken root and are eroded on the crown as well. The specimens are, on average, $3.14 \mathrm{~mm}$ high and $4.14 \mathrm{~mm}$ wide, approximately.

These teeth have an upright, triangular, and slender crown, with both cutting edges smooth. The mesial cutting edge has a sigmoidal to convex outline, whereas the distal cutting edge is convex to straight depending on the specimen observed (Figure 6f). The root of the only complete tooth, specimen UEBR_27.2, is not very elongated transversely, but presents, in lingual view, a subtle lingual protuberance (Figure 6e). The basal face of the root is flat. It is divided into two lobes by a deep and narrow furrow, located in the lingual protuberance, where the main foramen opens.

Discussion: Although the crown of the studied specimens resembles the one in the antero-lateral and lateral specimens of Scoliodon aff. laticaudus figured by Cappetta (2012, fig. 282), due to the poor state of preservation of the specimens, it was decided to leave the material in open nomenclature.

Genus Rhizoprionodon Compagno, 1988

Rhizoprionodon ficheuri (Joleaud, 1912)

Figure 6g,h

Physodon miocaenicus Jonet, 1965: plate 3, figs. 3-12.

Material: UEBR_28.1-UEBR_28.90, 90 isolated teeth.

Description: Small lateral teeth, wider than high, as seen in their average dimensions: $2.54 \mathrm{~mm}$ high per $4.54 \mathrm{~mm}$ wide, approximately. The crown's base is extended towards the distal edge of the tooth. The main cusp may present itself more or less convex, with the apex in some specimens mesially bent. The concave and sharp mesial cutting edge of the crown is fused with a slightly convex mesial heel. The convex distal cutting edge of the crown is also sharp with no serration, but it is clearly separated from the distal heel, which has a round outline in both labial and lingual views. In labial view, the labial face of the crown moderately overhangs the root (Figure 6h). The root is low and has a flat basal face, in lingual view, marked by a subtle lingual protuberance where a deep groove divides the root into two lobes (Figure 6g).

Discussion: The studied specimens were compared with upper and lower anterior and lateral teeth of Rhizoprionodon ganntourensis (Arambourg, 1952, plate XXVI, figs. 49-63) also figured by Cappetta and Nolf (1981, plate 1, figs. 8-18), and Samonds, Andrianavalona, Wallett, Zalmout and Ward (2019, fig. 4a-d). However, the specimens of $R$. ganntourensis show a distal denticle instead of the round distal heel present in the studied specimens.

The upper and lower anterior and lateral teeth of Rhizoprionodon taxandriae synonymy Scoliodon taxandriae Leriche, 1926 figured by Jonet (1965, plate 3, figs. 13-23) and Antunes and Jonet (1970, plate XIV, figs. 82-91), are shorter than the ones studied.

Only the specimens of Rhizoprionodon ficheuri figured by Vialle et al. (2011, figs. 3, 7), Cappetta (2012, fig. 283), Andrianavalona et al. (2015, fig. 4i,j), Pollerspöck and Straube (2017, fig. 4); and its synonymy Physodon miocaenicus figured by Jonet (1965, plate 3, figs. 3-12), 
TABLE 1 Quantity of fossil teeth per identified species, and respective relative

\begin{tabular}{lllll}
\hline Order & Species & Label & $\mathbf{n}$ & $\mathbf{f ( \% )}$ \\
\hline Hexanchiformes & Hexanchus cf. agassizi & UEBR_13 & 4 & 1.04 \\
\hline Squaliformes & Centrophorus cf. granulosus & UEBR_14 & 1 & 0.26 \\
\hline Squatiniformes & Squatina subserrata & UEBR_15 & 18 & 4.69 \\
Lamniformes & Carcharias acutissimus & UEBR_16 & 1 & 0.26 \\
& Otodus (Megaselachus) megalodon & UEBR_17 & 1 & 0.26 \\
& Alopias sp. & UEBR_18 & 7 & 1.82 \\
\hline \multirow{3}{*}{ Carcharhiniformes } & Megascyliorhinus sp. & UEBR_19 & 1 & 0.26 \\
& Pachyscyllium dachiardii & UEBR_20 & 29 & 7.55 \\
& Scyliorhinus sp. & UEBR_21 & 21 & 5.47 \\
& Galeorhinus goncalvesi & UEBR_22 & 39 & 10.16 \\
& lago angustidens & UEBR_23 & 6 & 1.56 \\
& Chaenogaleus affinis & UEBR_24 & 114 & 29.69 \\
& Hemipristis serra & UEBR_25 & 1 & 0.26 \\
& Galeocerdo aduncus & UEBR_26 & 1 & 0.26 \\
& Scoliodon sp. & UEBR_27 & 37 & 9.64 \\
& Rhizoprionodon ficheuri & UEBR_28 & 90 & 23.44 \\
Carcharhinus priscus & UEBR_29 & 13 & 3.39 \\
\hline Total & & 384 & \\
\hline
\end{tabular}

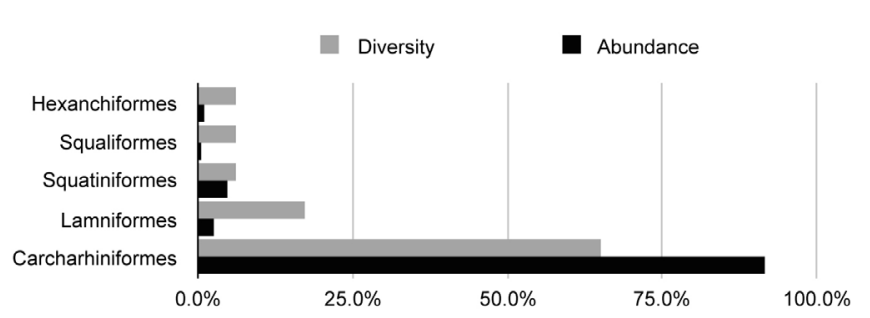

FIGURE 7 Graphic representation of the diversity of species and relative abundance of the fossil material, per Order

match the length of the teeth, the slightly bent apex of the crown and the overall outline and morphological characters of the teeth.

Genus Carcharhinus de Blainville, 1816

Carcharhinus priscus (Agassiz, 1843)

Figure 6i-I

Material: UEBR_30.1-UEBR_30.10, 10 isolated teeth.

Description: Small fragmented teeth, on average, $6.22 \mathrm{~mm}$ high and $6.70 \mathrm{~mm}$ wide.

The upper teeth have a triangular crown distally inclined. Both cutting edges present a serration that goes from the connection with the heels, also serrated, to the apex of the crown where it becomes absent. Whereas the mesial cutting edge of the crown is slightly convex and in most specimens only separated from the mesial heel by a subtle notch, the distal cutting edge is slightly concave to almost straight, and it is separated from the distal heel by a more marked notch. In labial view, the labial face of the crown is flat to slightly convex (Figure 6j). In lingual view, the lingual face of the crown is strongly convex, with a visible neck between the crown and the root. The crown is higher than the root, which presents a subtle lingual protuberance and a deep lingual groove, where the main foramen opens (Figure 6i).

The lower tooth (specimen UEBR_29.2, Figure 6k,l) has a similar morphology but it has a narrower cusp, erected and ornamented with a very subtle serration in both cutting edges. The root is transversely elongated and also divided into two lobes by a groove.

Discussion: The specimens were compared with several different forms of Carcharhinus, including recent teeth kindly donated by E. Santos from the living C. plumbeus (Nardo, 1827) sharks from the Lisbon Oceanarium. However, similarities were only found with two species, C. perezi (Poey, 1876) and C. priscus.

The connections between the cutting edges and the respective heels on the studied teeth are angular as in C. priscus figured by Carrillo-Briceño et al. (2019, fig. 5x-z'), Antunes et al. (1981, plate 2, fig. 18), and Godfrey (2018, fig. 2.22n-p), more so than the ones of C. perezi figured by Carrillo-Briceño et al. (2019, fig. 5v,w), Godfrey (2018, fig. 2.22k-m) and Antunes, Balbino and Cappetta (1999a, plate 1, figs. 1-7). Also, according to Godfrey (2018), C. priscus tends to the absence of serrations apically in the crown, which is seen in the studied specimens. Hence the attribution of the material to this species.

\section{$5 \mid$ RESULtS}

Through this study, more sediment was screened from the sampling performed at Brielas outcrop in 1995, and the material found was added to a total of 4,070 isolated fish fossils in the collection 
catalogue. Of these 1,046 are Teleostei teeth, which were not studied since the scope of this article is the diversity of fossil sharks. From selachians, there were 3,024 fossils recovered so far. The material associated with batoids accounts for $20.0 \%$ of the total selachians' fossil material, with 149 teeth previously classified (Fialho et al., 2019) and 457 fossils still in analysis. The fossil material of sharks constitutes $80.0 \%$, with 384 teeth ascribed to 17 species in the present work, as seen in Table 1, and 2,034 teeth fragments too broken for the systematic analysis to be conclusive at the genus level.

By comparing the number of specimens found per taxon, as presented in Figure 7, the less abundant Order, with only one specimen, was Squaliformes, followed by Hexanchiformes, Lamniformes, and Squatiniformes. The majority of the studied material (91.7\%) was attributed to Carcharhiniformes, which was also the most diversified Order with 11 species.

Taking into account the presence of the identified taxa in Portugal, the current work marks the first Portuguese occurrences of Centrophorus granulosus, Hexanchus cf. agassizi and lago angustidens. Pachyscyllium dachiardii was previously described by Antunes et al. (1999b) and Rhizoprionodon ficheuri synonymizes Physodon miocaenus Jonet, 1965 as proposed by Jonet (1965-1966). It is also worthy of note the new occurrence in Portugal, and for an older age, of the species Galeorhinus goncalvesi.

\section{6 | DISCUSSION AND CONCLUSIONS}

The current study adds 17 shark species (Table 1 ), to the 12 previously identified batoids of the same assemblage (Fialho et al., 2019), further supporting the richness of the Langhian marine facies of the Brielas outcrop. The species Centrophorus granulosus and lago angustidens were identified for the first time in the Portuguese geological record, whereas the material assigned to the Hexanchus genus could represent the first appearance of Hexanchus cf. agassizi in Miocene units of the country. The material for Pachyscyllium dachiardii and Rhizoprionodon ficheuri here described represents the second Portuguese occurrence for both species.

The species Galeorhinus goncalvesi was previously found in bulksamples from three geological sites (Esbarrondadoiro, Vale de Zebro and Santa Margarida) of the uppermost Miocene, 'mammal-zone' MNZ13, of the Esbarrondadoiro Formation, Alvalade Basin (Antunes et al., 1999b). However, the new material ascribed to this species, representing its second occurrence in the Portuguese geological record and for Langhian sediments of Brielas (Lower Tagus Basin), suggests that it appeared earlier than previously assumed by the authors.

A great diversity of forms was found, mainly demersal and associated with tropical to temperate waters, and littoral and neritic bathymetric zones (Antunes \& Jonet, 1970; Jonet, 1978; Pollerspöck \& Straube, 2019; Zbyszewski \& Moitinho de Almeida, 1950). Co-existing with these, there were also pelagic sharks such as Otodus (Megaselachus), Alopias, and Galeocerdo. This fossil shark diversity, matching the previous findings on the batoid diversity (Fialho et al., 2019), further supports a gradual transition of an infralittoral environment with warm waters and increasing depth, towards a circalittoral one as stated by Legoinha (2001), according to the study of the foraminifera in the outcrop. Moreover, it may also support the hypothesis presented by Fialho et al. (2019), that upwelling phenomena could explain this rich and diverse association of selachian forms found in a single fossil site.

Through the identification of these selachian taxa and their spatial distribution and chronological range, the current study will contribute to future researches focused on the evolution and distribution of these organisms.

\section{ACKNOWLEDGEMENTS}

We appreciate the donation of shark teeth from extant species of the Lisbon Oceanarium by E. Santos of the Lisbon Oceanarium, useful for the morphological comparison. We are grateful to J. Mirão and L. Dias, from HERCULES Laboratory of the University of Évora, for the thorough photographic record of the smallest specimens. We are especially grateful for the support provided during the initial systematic classification of the specimens by H. Cappetta, at the Institut des Sciences de I'Évolution de I'Université de Montpellier. We thank the reviewers who provided comments that helped us to improve the manuscript.

\section{ORCID}

Pedro R. Fialho (D) https://orcid.org/0000-0001-7813-0639

\section{REFERENCES}

Adnet, S., \& Martin, R. A. (2007). Increase of body size in sixgill sharks with change in diet as a possible background of their evolution. Historical Biology, 19, 279-289. https://doi.org/10.1080/08912960701194461.

Agassiz, L. (1833- 1843). Recherches sur les Poissons fossiles. Neuchâtel, Switzerland: Imprimerie Petitpierre et Prince, et Lithographie H. Nicolet.

Ameghino, F. (1901). L'âge des formations sédimentaires de Patagonie. Anales de la Sociedad Científica Argentina, 51, 20-39.

Andrianavalona, T. H., Ramihangihajason, T. N., Rasoamiaramanana, A., Ward, D. J., Ali, J. R., \& Samonds, K. E. (2015). Miocene Shark and Batoid Fauna from Nosy Makamby (Mahajanga Basin, Northwestern Madagascar). PLoS One, 10(6), 1-17. https://doi.org/10.1371/journal. pone.0129444.

Antunes, M. T. (1984). Essai de synthèse sur les mammifères du Miocène du Portugal. In G. Zbyszewski (Ed.), Volume d'Hommage au géologue G. Zbyszewski (pp. 301-323). Recherche sur les Civilisations: Paris, France.

Antunes, M. T. (2000). Miocene mammals from Lisbon and geologic age: A showcase for marine-continental correlations. Ciências da Terra, 14, 343-348.

Antunes, M. T., \& Balbino, A. C. (2003). Uppermost Miocene Lamniform Selachians (Pisces) from the Alvalade Basin (Portugal). Ciências da Terra, 15, 141-154.

Antunes, M. T., \& Balbino, A. C. (2004). Os Carcharhiniformes (Chondrichthyes, Neoselachii) da Bacia de Alvalade (Portugal). Revista Española de Paleontología, 19, 73-92 (in Portuguese with English abstract).

Antunes, M. T., Balbino, A. C., \& Cappetta, H. (1999a). Sélaciens du Miocène terminal du Bassin d'Alvalade (Portugal), essai de synthèse. Ciências da Terra, 13, 115-129 (in French with English abstract).

Antunes, M. T., Balbino, A. C., \& Cappetta, H. (1999b). A new shark, Galeorhinus goncalvesi nov. sp. (Triakidae, Carcharhiniformes) from the latest Miocene of Portugal. Tertiary Research, 19, 101-106. 
Antunes, M. T., \& Jonet, S. (1970). Requins de l'Helvétien supérieur et du Tortonien de Lisbonne. Revista da Faculdade de Ciências da Universidade de Lisboa, 16, 119-280.

Antunes, M. T., Jonet, S., \& Nascimento, A. (1981). Vertébrés (crocodiliens, poissons) du Miocène marin de l'Algarve occidentale. Ciências da Terra, 6, 9-38 (in French with English abstract).

Antunes, M. T., Legoinha, P., \& Balbino, A. C. (2015). Megalodon, mako shark and planktonic foraminifera from the continental shelf off Portugal and their age. Geologica Acta, 13, 181-190. https://doi.org/10. 1344/GeologicaActa2015.13.3.1.

Antunes, M. T., Legoinha, P., Nascimento, A., \& Pais, J. (1996). The evolution of the Lower Tagus Basin (Lisbon and Setúbal Peninsula, Portugal) from Lower to Early Middle Miocene. Géologie de la France, 4, 59-77.

Antunes, M. T., Legoinha, P., Proença Cunha, P., \& Pais, J. (2000). High resolution stratigraphy and Miocene facies correlation in Lisbon and Setúbal Peninsula (Lower Tagus Basin, Portugal). Ciências da Terra, 14, 183-190.

Arambourg, C. (1952). Les vertébrés fossiles des gisements de phosphates (Maroc-Algérie-Tunisie). Notes et Mémoires du Service Géologique du Maroc, 92, 1-372.

Balbino, A. C. (1995). Seláceos (pisces) do Miocénico terminal da Bacia de Alvalade (Portugal): Sistemática, ecologia, paleoambientes, comparação com faunas actuais (PhD dissertation). University of Évora, pp. 1-188.

Bengtson, P. (1988). Open nomenclature. Palaeontology, 31(1), 223-227.

Berg, L. S. (1937). A classification of fish-like vertebrates. Bulletin de l'Académie des Sciences de I'URSS, 4, 1277-1280.

Berggren, W. A., Kent, D. V., Aubry, M.-P., \& Hardenbol, J. (Eds.). (1995). Geochronology, time scales and global stratigraphic correlation. Special Publication (Vol. 54, pp. 1-386). Broken Arrow, OK: SEPM - Society of Sedimentary Geology. https://doi.org/10.2110/pec.95.04.

Bleeker, P. (1859). Enumeratio specierum piscium hucusque in Archipelago indico observatarum. Acta Societatis scientiarum Indo-Neerlandae, 6, 1-276.

Bloch, M. E., \& Schneider, J. G. (1801). M. E. Blochii Systema Ichthyologiae iconibus ex illustratum. Post obitum auctoris opus inchoatum absolvit, correxit, interpolavit. Jo. Gottlob Schneider, Saxo, 2, 1-584. https://doi. org/10.5962/bhl.title.5750.

Blow, W. H. (1969). Late Middle Eocene to recent planktonic foraminiferal biostratigraphy. P. Bronnimann \& H. H. Renz. In Proceedings of the 1st International Conference on Planktonic Microfossils (Vol. 1, pp. 199422). Geneva: Switzerland.

Bonaparte, C. L. (1838). Selachorum tabula analytica. Nuovi Annali della Science Naturali Bologna, 2, 195-214.

Bonnaterre, J. P. (Ed.). (1788). Tableau encyclopédique et méthodique des trois règnes de la nature: Ichthyologie (pp. 1-215). Paris, France: Chez Panckoucke. https://doi.org/10.5962/bhl.title.11660.

Brisswalter, G. (2008). Inventaire des Élasmobranches (requins, raies, chimères) des dépôts molassiques du Sud-Luberon (Miocène supérieur). In Courriers scientifiques du Parc Régional du Lubéron, Hors Série (pp. 1-100). Apt, France: PNRL.

Cappetta, H. (1970). Les Sélaciens du Miocène de la région de Montpellier, palaeovertebrata. In Mémoire extraordinaire (pp. 1-139). Montpellier, France: Laboratoire de Paléontologie des Vertébrés.

Cappetta, H. (1973). Les Sélaciens du Burdigalien de Lespignan (Hérault). Geobios, 6(3), 211-223 (in French with English abstract). https://doi. org/10.1016/S0016-6995(73)80016-6.

Cappetta, H. (1976). Sélaciens nouveaux du London Clay de I'Essex (Yprésien du bassin de Londres). Geobios, 9(5), 551-575(in French with English abstract). https://doi.org/10.1016/S0016-6995(76)80024-1.

Cappetta, H. (1987). Chondrichthyes II: Mesozoic and Cenozoic Elasmobranchii. In H. -P. Schultze (Ed.), Handbook of paleoichthyology (Vol. 3B, pp. 1-193). Munich, Germany: Verlag Dr. Friedrich Pfeil.

Cappetta, H. (1992). Carcharhiniformes nouveaux (Chondrichthyes, Neoselachii) de l'Yprésien du Bassin de Paris. Geobios, 25(5), 639-646. https://doi.org/10.1016/0016-6995(92)80103-K.
Cappetta, H. (2012). Chondrichthyes: Mesozoic and Cenozoic Elasmobranchii teeth. In H. -P. Schultze (Ed.), Handbook of paleoichthyology (Vol. 3E, pp. 1-512). Munich, Germany: Verlag Dr. Friedrich Pfeil.

Cappetta, H., \& Nolf, D. (1981). Les sélaciens de l'Auversien de Ronquerolles (Eocène supérieur du Bassin de Paris). Mededelingen van de Werkgroep voor Tertiaire en Kwartaire Geologie, 18(3), 87-107.

Cappetta, H., \& Ward, D. (1977). Megascyliorhinus cooperi gen. nov. sp. nov., a new shark from the London Clay (Eocene) of Essex, England. Palaeontology, 20(1), 195-202.

Carlsen, A. W., \& Cuny, G. (2014). A study of the sharks and rays from the Lillebaelt Clay (Early-Middle Eocene) of Denmark, and their palaeoecology. Bulletin of the Geological Society of Denmark, 62, 39-88.

Carrillo-Briceño, J. D., Aguilera, O. A., De Gracia, C., Aguirre-Fernández, G., Kindlimann, R., \& Sánchez-Villagra, M. R. (2016). An Early Neogene elasmobranch fauna from the southern Caribbean (western Venezuela). Palaeontologia Electronica, 19(2), 1-32. https://doi.org/10. 26879/664.

Carrillo-Briceño, J. D., Luz, Z., Hendy, A., Kocsis, L., Aguilera, O., \& Vennemann, T. (2019). Neogene Caribbean elasmobranchs: Diversity, paleoecology and paleoenvironmental significance of the Cocinetas Basin assemblage (Guajira Peninsula, Colombia). Biogeosciences, 16, 33-56. https://doi.org/10.5194/bg-16-33-2019.

Case, G. R. (1980). A selachian fauna from the Trent Formation, Lower Miocene (Aquitanian) of Eastern North Carolina. Palaeontographica, Abteilung A - Band A, 171(1-3), 75-103.

Charlesworth, E. (1837). Notice of the teeth of Carcharias megalodon occurring in the Red Crag of Suffolk. Magazine of Natural History, 1(2), 225-227.

Cicimurri, D. J., \& Knight, J. L. (2009). Late Oligocene sharks and rays from the Chandler Bridge Formation, Dorchester County, South Carolina, USA. Acta Palaeontologica Polonica, 54, 627-647. https://doi.org/10. 4202/app.2008.0077.

Compagno, L. F. V., \& Springer, S. (1971). lago, a new genus of carcharhinid sharks, with a redescription of I. omanensis. Fishery Bulletin, 69(3), 615-626.

Compagno, L. J. V. (1973). Interrelationships of living elasmobranchs. Zoological Journal of the Linnean Society, 53(Supplement 1), 15-61.

Compagno, L. J. V. (1977). Phyletic relationships of living sharks and rays. American Zoologist, 17(2), 303-322.

Compagno, L. J. V. (Ed.). (1988). Sharks of the order Carcharhiniformes (pp. 1-486). Princeton, USA: Princeton University Press.

Cotter, J. C. B. (1956). O Miocénico marinho de Lisboa. Comunicações dos Serviços Geológicos de Portugal, 36(Supplement), 1-170.

D'Anastasio, R., López-Lázaro, S., \& Viciano, J. (2018). Dientes Fósiles de Carcharocles megalodon: La Colección del Museo Universitario de Chieti (Italia). Parte II: Análisis Paleopatológico. International Journal of Morphology, 36(3), 841-847 (in Spanish with English abstract).

Dames, W. (1883). Über eine tertiäre Wirbelthierfauna von der westlichen Insel der Birket-El-Qrûn im Fajum (Aegypten). Sitzungsberichte der Königlich Preussischen Akademie der Wissenschaften zu Berlin, 6, 129-153.

de Blainville, H. M. D. (1816). Prodrome d'une nouvelle distribution systématique du règne animal. Bulletin de la Société Philomathique de Paris (Vol. 8, pp. 105-124).

de Buen, F. (1926). Catálogo ictiológico del Mediterráneo español y de Marruecos, recopilando lo publicado sobre peces de las costas mediterránea y próximas del Atlántico (Mar de España). In Resultados de las campañasrealizadas por acuerdos internacionales (Vol. 2, pp. 1-221). Spain: Instituto Español de Oceanografía.

Duméril, A. M. C. (1806). Zoologie analytique, ou méthode naturelle de classification des animaux (pp. 1-344). Paris, France: Librairie Allais. https:// doi.org/10.5962/bhl.title.11646.

Fialho, P., Balbino, A., \& Antunes, M. T. (2019). Langhian rays (Chondrichthyes, Batomorphii) from Brielas, Lower Tagus Basin, 
Portugal. Geologica Acta, 17(7), 1-16. https://doi.org/10.1344/ GeologicaActa2019.17.7.

García, E. X. M., Balbino, A. C., Antunes, M. T., Ruiz, F., Civis, J., Abad, M., \& Toscano, A. (2011). Los tiburones Carcharhiniformes (Chondrichthyes, Galeomorphii) del Plioceno inferior de la Formación Arenas de Huelva, suroeste de la cuenca del Guadalquivir, España. Revista Mexicana de Ciencias Geológicas, 28, 474-492 (in Spanish with English abstract).

Gill, T. (1862). Analytical synopsis of the Order of Squali and revision of the nomenclature of the genera. Annals of the Lyceum of Natural History of New York, 7(32), 371-408. https://doi.org/10.1111/j.17496632.1862.tb00166.x.

Glikman, L. S. (Ed.). (1964). Sharks of Paleogene and their stratigraphic significance] (in Russian) (pp. 1-229). Moscow, Russia: Nauka Press.

Godfrey, S. J. (Ed.). (2018). The geology and vertebrate paleontology of Calvert Cliffs, Maryland, USA (pp. 1-282). Washington, DC: Smithsonian Institution Scholarly Press.

Goedert, J., Amiot, R., Arnaud-Godet, F., Cuny, G., Fourel, F., Hernandez, J. -A., ... Lécuyer, C. (2017). Miocene (Burdigalian) seawater and air temperatures estimated from the geochemistry of fossil remains from the Aquitaine Basin, France. Palaeogeography, Palaeoclimatology, Palaeoecology, 481, 14-28. https://doi.org/10.1016/j. palaeo.2017.04.024.

Goodrich, E. S. (1909). Vertebrata Craniata (First fascicle: Cyclostomes and fishes). In E. R. Lankester (Ed.), A treatise on zoology (pp. 1-518). London, England: Adam and Charles Black.

Gray, J. E. (Ed.). (1851). List of the specimens of fish in the collection of the British Museum, Part I, Chondropterygii, (1-160). London, England: Natural History Museum.

Haq, B. U., Hardenbol, J., \& Vail, P. R. (1987). Chronology of fluctuating sea levels since the Triassic. Science, 235(4793), 1156-1167. http:// dx.doi.org/10.1126/science.235.4793.1156.

Hasse, J. C. F. (Ed.). (1879). Das natürliche System der Elasmobranchier auf Grundlage des Baues und der Entwicklung ihrer Wirbelsäule. Eine morphologische und paläontologische Studie (pp. 1-76). Jena, Germany: Verlag von Gustav Fisher. https://doi.org/10.5962/bhl.title.8431.

Hay, O. P. (1902). Bibliography and catalogue of the fossil vertebrata of North America. Bulletin of the United States Geological Survey, 179, 1-868.

Huxley, T. H. (1880). On the application of the laws of evolution to the arrangement of the Vertebrata, and more particularly of the Mammalia. Proceedings of the Zoological Society of London, 649-662.

Joleaud, L. (1912). Géologie et Paléontologie de la Plaine du Comtat et de ses abords. In Description des terrains néogènes (Vol. 2, pp. 255-285). Montpellier, France: Imprimerie Montane, Sicardi et Valentin.

Jonet, S. (1965-1966). Notes d'ichthyologie miocène. II. Les Carcharhinidae. In Boletim do Museu e Laboratório Mineralógico e Geológico da Faculdade de Ciências (Vol. 10(2), pp. 65-88).

Jonet, S. (1978). Le Tortonien supérieur (TVII-b) des environs de Fonte de Telha (Peninsule de Setúbal) et ses faunes. Comunicações dos Serviços Geológicos de Portugal, 63, 13-51.

Jordan, D. S., \& Evermann, B. W. (1896). The fishes of North and Middle America, a descriptive catalogue of the species of fish-like vertebrates found in the waters of North America, north of the isthmus of Panama. Part. I. Bulletin of the United States National Museum, 47, 1-1240.

Jordan, D. S., \& Hannibal, H. (1923). Fossil sharks and rays of the Pacific slope of North America. Bulletin of the Southern California Academy of Sciences, 22, 27-63.

Jordan, D. S., \& Snyder, J. O. (1902). Descriptions of two new species of squaloid sharks from Japan. Proceedings of the United States National Museum, 25(1279), 79-87.

Jost, J., Kempf, O., \& Kälin, D. (2016). Stratigraphy and palaeoecology of the Upper Marine Molasse (OMM) of the central Swiss Plateau. Swiss Journal of Geosciences, 109, 149-169. https://doi.org/10.1007/ s00015-016-0223-6.
Keyes, I. W. (1984). New records of fossil elasmobranch genera Megascyliorhinus, Centrophorus, and Dalatias (Order Selachii) in New Zealand. New Zealand Journal of Geology and Geophysics, 27, 203-216.

Laurito, C. A. (2015). Nuevos registros fósiles de Otodus (Megaselachus) chubutensis [Ameghino, 1901 a 1902] para el Mioceno Inferior de Costa Rica, América Central. Revista Geológica de América Central, 6167, 53. (in Spanish with English abstract) https://doi.org/10.15517/ RGAC.V53I0.21141.

Laurito Mora, C. A. (Ed.). (1999). Los Seláceos fósiles de la localidad de Alto Guayacán (y otros ictiolitos asociados): Mioceno-Superior-Plioceno Inferior de la formación Uscari, provincia de Limón (pp. 1-168). San José, Costa Rica: Texto Comunicación.

Lawley, R. (Ed.). (1876). Nuovi studi sopra ai pesci ed altri vertebrati fossili delle Colline Toscane (pp. 1-122). Florence, Italy: Tipografia dell Arte della Stampa.

Leder, R. M. (2013). Eocene Carcharinidae and Triakidae (Elasmobranchii) of Crimea and Kazakhstan. Leipziger Geowissenschaften, 20, 1-57.

Legoinha, P. (2001). Biostratigrafia de foraminíferos do Miocénico de Portugal (PhD dissertation). Lisboa, Portugal: Universidade Nova de Lisboa.

Legoinha, P., \& Flores, J. A. (2014). Refinement of the biostratigraphy and biochronology of the Belverde borehole (Setúbal Peninsula, Portugal) using calcareous nannofossil data. In R. Rocha, J. Pais, J. C. Kullberg, \& S. Finney (Eds.), STRATI 2013: First international congress on stratigraphy, at the cutting edge of stratigraphy (pp. 1119-1122). Cham, Switzerland: Springer International.

Leriche, M. (1926). Les poissons tertiaires de Belgique, IV, Les poissons néogènes. Mémoires du Musée Royal d'Histoire Naturelle de Belgique, 32, 367-472.

Leriche, M. (1927). Les Poissons de la Molasse suisse. Mémoires de la Société Paléontologique Suisse, 46, 1-55.

Lesueur, C. A. (1822). Description of a Squalus, of a very large size, which was taken on the coast of New Jersey. Journal of the Academy of Natural Sciences of Philadelphia, 2(1), 343-352.

Linnaeus, C. (1758). Systema naturae per regna tria naturae, secundum classes, ordines, genera, species, cum characteribus, differentiis, synonymis, locis (ed. X ed., p. 824). Stockholm, Sweden: Laurentii Salvii.

Lowe, R. T. (1841). A paper from the Rev. R.T. Lowe, M.A., describing certain new species of Madeiran fishes, and containing additional information relating to those already described. Proceedings of the Zoological Society of London, 8, 36-39.

Maisch, H. M., Becker, M. A., \& Chamberlain, J. A. (2018). Lamniform and carcharhiniform sharks from the Pungo River and Yorktown formations (Miocene-Pliocene) of the submerged continental shelf, Onslow Bay, North Carolina, USA. Copeia, 106, 353-374. https://doi.org/10. 1643/OT-18-016.

Martini, E. (1971). Standard tertiary and quaternary calcareous nannoplankton zonation. In A. Farinacci (Ed.), Proceedings of the 2nd planktonic conference (Vol. 2, pp. 739-785). Rome, Italy: Edizioni Tecnoscienza.

Mein, P. (2000). La biochronologie des mammifères néogènes d'Europe. Ciências da Terra, 14, 335-342 (in French with English abstract).

Müller, J., \& Henle, F. G. J. (Eds.). (1841). Systematische Beschreibung der Plagiostomen (pp. 1-200). Berlin, Germany: Verlag von Veit \& comp. https://doi.org/10.5962/bhl.title.6906.

Müller, J., \& Henle, F. G. J. (1837). Gattungen der Haifische und Rochen nach einer von ihm mit Hrn. Henle unternommenen gemeinschaftlichen Arbeit über die Naturgeschichte der Knorpelfische. Berichte der Königlichen Preussischen Akademie der Wissenschaften zu Berlin, 1837(2), 111-118.

Müller, J., \& Henle, F. G. J. (1838). Ueber die Gattungen der Plagiostomen. Archiv für Naturgeschichte, 4, 83-85.

Münster, G. G. (1846). Ueber die in der Tertiär-Formation des Wiener Beckens vorkommenden Fisch-Ueberreste, mit Beschreibung einiger neuen merkwürdigen Arten. Beiträge zur Petrefactenkunde, 7, 1-31. 
Nardo, G. D. (1827). Prodromus observationum et disquisitionum Adriaticae ichthyologiae. Giornale Di Fisica, Chimica, Storia Naturele, Medicina, Ed Arti, 2, 22-40.

Naylor, G. J., Caira, J. N., Jensen, K., Rosana, K. A., Straube, N., \& Lakner, C. (2012). Elasmobranch phylogeny: A mitochondrial estimate based on 595 species. In J. Carrier, J. A. Musick, \& M. R. Heithaus (Eds.), Biology of sharks and their relatives (pp. 31-56). Boca Raton, FL: CRC Press.

Pais, J., Cunha, P. P., Pereira, D., Legoinha, P., Dias, R., Moura, D., ... GonzálezDelgado, J. A. (2012). The Paleogene and Neogene of Western Iberia (Portugal): A Cenozoic record in the European Atlantic domain. Berlin, Germany: Springer-Verlag. https://doi.org/10.1007/978-3-642-22401-0_1.

Perez, V. J., Pimiento, C., Hendy, A., González-Barba, G., Hubbell, G., \& MacFadden, B. J. (2017). Late Miocene chondrichthyans from Lago Bayano, Panama: Functional diversity, environment and biogeography. Journal of Paleontology, 91, 512-547. https://doi.org/10.1017/jpa. 2017.5.

Pfeil, F. H. (1984). Neoselachian teeth collected from phosphorite-bearing greensand on Chatham Rise east of New Zealand. Geologisches Jahrbuch, 65, 107-115.

Poey, F. (1876). Enumeratio piscium cubensium (Parte III). In Anales de la Sociedad Española de Historia Natural (Vol. 5, pp. 373-404).

Pollerspöck, J., \& Beaury, B. (2014). Eine Elasmobranchierfauna (Elasmobranchii, Neoselachii) aus der Oberen Meeresmolasse (Ottnangium, Unteres Miozän) des Heigelsberger Grabens bei Teisendorf, Oberbayern. Zitteliana, 54, 23-37 (in German with English abstract). https://doi.org/10.5282/ubm/epub.22321.

Pollerspöck, J., \& Straube, N. (2017). A new deep-sea elasmobranch fauna form the Central Paratethys (Neuhofener Beds, Mitterdorf, near Passau, Germany, Early Miocene, Middle Burdigalian). Zitteliana, 90, 27-53. https://doi.org/10.5282/ubm/epub.40476.

Pollerspöck, J., \& Straube, N. (2019). Bibliography database of living/fossil sharks, rays and chimaeras (Chondrichthyes: Elasmobranchii, Holocephali). World Wide Web electronic publication. Retrieved from www.sharkreferences.com

Probst, J. (1878). Beiträge zur Kenntniss der fossilen Fische aus der Molasse von Baltringen. Jahreshefte des Vereins für vaterländische Naturkunde in Württemberg, 34, 113-154.

Probst, J. (1879). Beiträge zur Kenntniss der fossilen Fische aus der Molasse von Baltringen. Jahreshefte des Vereins für vaterländische Naturkunde in Württemberg, 35, 127-191.

Rafinesque, C. S. (Ed.). (1810). Caratteri di alcuni nuovi generi e nuove specie di animali e pinate della Sicilia, con varie osservazioni sopra i medisimi, lère partie (pp. 1-105). Palermo, Italy: Per le stampe di Sanfilippo. https://doi.org/10.5962/bhl.title.104418.

Ralte, V. Z., Tiwari, R. P., Lalchawimawii, \& Malsawma, J. (2011). Selachian fishes from Bhuban Formation, Surma Group, Aizawl, Mizoram. Journal of the Geological Society of India, 77, 328-348. https://doi.org/10. 1007/s12594-011-0036-1.

Reinecke, T. (2014). Two new scyliorhinid shark species (Elasmobranchii, Carcharhiniformes, Scyliorhinidae), from the Sülstorf Beds (Chattian, Late Oligocene) of the southeastern North Sea Basin, northern Germany. Palaeovertebrata, 38(1), 1-8. https://doi.org/10.18563/pv.38.1.e1.

Reinecke, T., Moths, H., Grant, A., \& Breitkreuz, H. (2005). Die Elasmobranchier des norddeutschen Chattiums, insbesondere des Sternberger Gesteins (Eochattium, Oligozän). Palaeontos, 8, 1-135.

Samonds, K. E., Andrianavalona, T. H., Wallett, L. A., Zalmout, I. S., \& Ward, D. J. (2019). A Middle-Late Eocene neoselachian assemblage from nearshore marine deposits, Mahajanga Basin, northwestern Madagascar. PLoS One, 14(2), 1-20. https://doi.org/10.1371/journal.pone. 0211789.

Schultz, O., Brzobohatý, R., \& Kroupa, O. (2010). Fish teeth from the Middle Miocene of Kienberg at Mikulov, Czech Republic, Vienna Basin. Annalen des Naturhistorischen Museums in Wien, Serie A, 112, 489-506.

Sigovini, M., Keppel, E., \& Tagliapietra, D. (2016). Open nomenclature in the biodiversity era. Methods in Ecology and Evolution, 7, 1217-1225. https://doi.org/10.1111/2041-210X.12594.

Sismonda, E. (1861). Appendice alla descrizione dei pesci e dei crostacei fossili nel Piemonte. Memorie della Reale Accademia della Scienze di Torino, 19, 453-474.

Snedden, J. W., \& Liu, C. (2010). A compilation of phanerozoic sea-level change, coastal onlaps and recommended sequence designations. Search and discovery, 40594.

Underwood, C. J., Ward, D. J., King, C., Antar, S. M., Zalmout, I. S., \& Gingerich, P. D. (2011). Shark and ray faunas in the Middle and Late Eocene of the Fayum area, Egypt. Proceedings of the Geologists' Association, 122, 47-66. https://doi.org/10.1016/j.pgeola.2010.09.004.

Vialle, N., Adnet, S., \& Cappetta, H. (2011). A new shark and ray fauna from the Middle Miocene of Mazan, Vaucluse (southern France) and its importance in interpreting the paleoenvironment of marine deposits in the southern Rhodanian Basin. Swiss Journal of Palaeontology, 130, 241-258. https://doi.org/10.1007/s13358-0110025-4.

Ward, D. J. (1978). Additions to the fish fauna of the English Palaeogene. 1. Two new species of Alopias (Thresher Shark) from the English Eocene. Tertiary Research, 2(1), 23-28.

Ward, D. J., \& Galea Bonavia, C. (2001). Additions to, and a review of, the Miocene shark and ray fauna of Malta. The Central Mediterranean Naturalist, 3, 131-146.

Weigmann, S. (2016). Annotated checklist of the living sharks, batoids and chimaeras (Chondrichthyes) of the world, with a focus on biogeographical diversity. Journal of Fish Biology, 88, 837-1037. https://doi. org/10.1111/jfb.12874.

Weigmann, S. (2017). Supplementary Table II (as of November 26, 2016) of annotated checklist of the living sharks, batoids and chimaeras (Chondrichthyes) of the world, with a focus on biogeographical diversity by Weigmann (2016). Journal of Fish Biology, 90, 1176-1118.

Westgate, J. W. (1984). Lower vertebrates from the Late Eocene Crow Creek local fauna, St. Francis County, Arkansas. Journal of Vertebrate Paleontology, 4, 536-546.

White, E. I. (1956). The Eocene fishes of Alabama. Bulletins of American Paleontology, 36(156), 123-150.

Zbyszewski, G., \& Moitinho de Almeida, F. (1950). Os peixes miocénicos portugueses. Comunicações dos Serviços Geológicos de Portugal, 31, 309-412.

How to cite this article: Fialho PR, Balbino AC, Legoinha P, Antunes MT. Shark fossil diversity (Squalomorphii, Squatinomorphii, and Galeomorphii) from the Langhian of Brielas (Lower Tagus Basin, Portugal). Geological Journal. 2020; 1-17. https://doi.org/10.1002/gj.3965 